\title{
Which School for Whom? Placement Choices for Inclusion or Exclusion of Dutch Students With Social, Emotional, and Behavioral Difficulties in Primary Education
}

\author{
Inge Zweers \\ Utrecht University and De Ambelt \\ Jan O. Bijstra \\ Regional Centre of Expertise for EBD Schools (RENN4) \\ Bram Orobio de Castro \\ Nouchka T. Tick \\ Utrecht University \\ Rens A. G. J. van de Schoot \\ Utrecht University and Optenia Research Program, North-West University
}

\begin{abstract}
This study examined which factors were related to placement choices for inclusive regular education or exclusive special education for Dutch students with social, emotional, and behavioral difficulties (SEBD). Students aged 6-11 in three subgroups participated: 45 included and 17 excluded students with SEBD (i.e., educated in regular education classrooms and in a separate setting exclusively for students with SEBD, respectively) and 772 typically developing peers. Before placement choices had been made, we collected data from students and teachers during classroom surveys and individual testing sessions with students with SEBD and from application files. Using Bayesian statistics, we found that included and excluded students with SEBD were similar in student functioning prior to placement, whereas teachers of included students had lower self-efficacy and more positive attitudes toward inclusion than teachers of excluded students. Furthermore, included and excluded students perceived their socialemotional functioning more negatively than typically developing peers. Hence, although considered essential by existing policies, placement choices may not depend on student functioning, but teacher factors may play a role.
\end{abstract}

Keywords: social/emotional/behavioral difficulties, placement choice, self-perception, teacher self-efficacy, teacher attitude, Bayes

Students with social, emotional, and behavioral difficulties (SEBD) have mental health problems that substantially disrupt their ability to function emotionally, socially, and academically (Cannon, Gregory, \& Waterstone, 2013). Specifically, the majority of students with SEBD shows both internalizing and externalizing behavior problems (Furlong,
Morrison, \& Jimerson, 2004; Gresham \& Kern, 2004; Landrum, 2011); problems in social functioning, such as difficulties in peer and adult relationships (Furlong et al., 2004; Gresham \& Kern, 2004); and impaired task-related behavior and academic performance, such as lower achievement scores (Cannon et al., 2013; Furlong et al., 2004; Reid, Gonzalez,

Author Note: This research was supported by de Ambelt. De Ambelt had no involvement in the conduct of the research and/or preparation of the article. The fifth author was supported by a grant from the Netherlands Organization for Scientific Research: NWO-VIDI-452-14-006. The first and second authors were employed by the institutions for special education services in The Netherlands in which the data for this study were collected. They do not have any financial or nonfinancial interest in these services or placement choices made by these services.

Correspondence regarding this article to Inge Zweers, ROC van Twente, MBO College voor Dienstverlening \& Gastvrijheid, P.O. Box 809, 7600 AV Almelo, The Netherlands; e-mail: izweers@ rocvantwente.nl

Copyright 2019 by the National Association of School Psychologists ISSN 0279-6015, eISSN 2372-966x 
Nordness, Trout, \& Epstein, 2004), for example, in reading (McKenna, Kim, Shin, \& Pfannenstiel, 2017). These broad descriptions suggest that students with SEBD comprise a considerably heterogeneous population of students with a variety of disorders, such as conduct disorder (CD), oppositional defiant disorder, autism spectrum disorder (ASD), and attention deficit hyperactivity disorder (ADHD). Although the problems that students with SEBD face are diverse, research has consistently shown that they are severe, pervasive, and chronic, resulting in adverse prospects in later life (e.g., Cannon et al., 2013).

Students with SEBD whose emotional and behavioral problems severely limit their participation in regular education have special educational needs. Schools can provide these students with the additional support they require. In the Netherlands, schools and parents have to apply for eligibility for special education services with independent committees. Once eligibility has been established by the independent committees, a placement choice has to be made between two possibilities. One possibility is that special education services, such as an individually adjusted work place or remedial teaching, will be provided in the regular education classroom (i.e., inclusion); in this scenario, students with SEBD are educated together with typically developing peers at all times. In some cases, students with SEBD may leave the classroom for a limited amount of time per week to receive supplementary services, such as social skills training or professional behavioral support, but they receive their core instruction within the regular education classroom. The other possibility is that the student with SEBD will receive special education services in a school for special education that exclusively educates students with special educational needs (i.e., exclusion). That is, students with SEBD are educated solely with students who also need additional support in a specialized setting, and they do not have opportunities to interact with typically developing peers in school. They reside in smaller classrooms in which they follow a more structured daily educational program, and they are supported by teachers trained to predict, understand, and replace disruptive and inappropriate behavior. Hence, applied to the educational situation of students with SEBD, three subgroups of students can be distinguished: typically developing students receiving no additional support, included students with SEBD receiving additional support in regular education, and excluded students with SEBD receiving additional support in a separate setting. In light of the far-reaching consequences of these placement decisions for the future of children with SEBD (e.g., students who received exclusive special education find jobs less often and are more often dependent on unemployment benefits than students in inclusive education; De Roos \& Bloem, 2014), surprisingly little research has examined the determinants of these placement choices.

The Dutch educational system described earlier originated from the international movement toward inclusive education, which has, in the last decades, taken place in the Netherlands as well as in many other countries (CRPD; see Ledoux, Roeleveld, Van Langen, \& Smeets, 2012; Oh-Young \& Filler, 2015; United Nations, 2006). It is unclear, however, which educational context is best for the development of students with SEBD. Although advantages of inclusion for the development of students with SEBD have been highlighted by some researchers and practitioners (e.g., Ruijs \& Peetsma, 2009; Van Leeuwen, Thijs, \& Zandbergen, 2009), others have emphasized the benefits of exclusive special education (Crnic \& Neece, 2015; Kauffman \& Badar, 2014; Lane, Wehby, Little, \& Cooley, 2005). Reasons to include students with SEBD in regular education are that exposure to the regular curriculum increases academic knowledge and skill acquirement and that students with SEBD who are surrounded by typically developing peers will be provided with ample opportunities to improve social skills. Reasons to provide special education services in exclusive schools for special education are that students may benefit from highly specialized environments in which instruction is tailored to their unique needs and in which professional and paraprofessional behavioral and therapeutic support is available (Lane et al., 2005; Tankersley, Landrum, \& Cook, 2004). In practice, however, a placement choice is based on various criteria related to the student's functioning without receiving additional support. Based on a combination of school and parent observations of the problems and subsequent needs of the student and the schools' ability to manage student behaviors, schools and parents consider which educational context will best meet the needs of the specific student with SEBD. Although placement choices are daily business in schools, not much is known about how different aspects contribute to them. A first step toward examining in which educational context students with SEBD develop best is to investigate which factors are related to such choices.

\section{Student Functioning}

Studies that compared included and excluded students with SEBD have suggested that placement decisions are related to students' emotional and behavioral functioning before placement. Specifically, studies have consistently found that students with SEBD who were placed in exclusive special education showed more severe externalizing (Bijstra, 2004; Drost \& Bijstra, 2008; Ledoux et al., 2012; Stoutjesdijk \& Scholte, 2009) and internalizing behavior problems (Drost \& Bijstra, 2008; Ledoux et al., 2012; Stoutjesdijk \& Scholte, 2009; Stoutjesdijk, Scholte, \& Swaab, 2012) before placement choices had been made than students with SEBD who were included in regular education. Bijstra (2004), in contrast, did not find differences between groups in internalizing behavior problems. In addition, research has shown that students with SEBD who were later placed in exclusive special education were more often classified with ADHD before placement choices had been made than students with SEBD who were later included in regular education (Drost \& Bijstra, 2008; Stoutjesdijk \& Scholte, 2009), although Stoutjesdijk and Scholte (2009) did not find differences between groups in parent- and teacher-reported attention problems. 
Factors related to student-teacher interactions and peer interactions may also play a role in placement choices. Studies that examined student-teacher relationships have consistently found that students with SEBD have worse student-teacher relationships than typically developing students, irrespective of regular or special educational context (e.g., Breeman et al., 2015; Ledoux et al., 2012; Little \& Kobak, 2003). Studentteacher relationships of students with SEBD were characterized by less closeness (i.e., openness, warmth, and security) and more conflict (i.e., negativity, discordance, unpredictability, and unpleasantness) and dependency (i.e., overreliance and possessiveness; Ledoux et al., 2012). However, these studies compared students who reside in different educational contexts after placement choices have been made. Teachers in exclusive special education are trained to meet the multiple needs of students with SEBD (Kauffman \& Badar, 2014; Lane et al., 2005), which may impact the student-teacher relationship, whereas before placement, teachers in regular education may feel unprepared to support students with SEBD (e.g., Jones \& Chronis-Tuscano, 2008).

Studies that examined relationships among students with SEBD have found that peer relationships of this population differ between regular or special educational contexts. In regular education, students with SEBD generally have worse relationships with peers than typically developing students (Poulin \& Boivin, 2010; Useche, Sullivan, Merk, \& Orobio de Castro, 2014), but not all studies support this (Farmer \& Hollowell, 1994). In exclusive special education, students with SEBD have also been found to have worse peer relationships than typically developing students in regular education (Little \& Kobak, 2003), although another study has even found better peer relationships for aggressive children in exclusive special education than for those in regular education (Useche et al., 2014). Again, it is unknown whether such differences were already present before placement choices were made. In regular education, students with SEBD are surrounded by typically developing peers; a context in which deviation from behavioral norms may result in unpopularity and rejection (Boivin, Petitclerc, Feng, \& Barker, 2010; Useche et al., 2014). In exclusive special education, students with SEBD are surrounded by peers with SEBD. Their problems may therefore have less impact on their likeability among peers (Useche et al., 2014).

Academic functioning may also play a role in placement choices. Studies that compared academic functioning of included and excluded students with SEBD have suggested that the latter group performs worse on task-related behavior (Ledoux et al., 2012), but for reading, spelling, and math, results have been mixed. Specifically, some studies have shown that students with SEBD who were referred to exclusive special education performed worse on reading (Lane et al., 2005; Ledoux et al., 2012), spelling (Lane et al., 2005; Stoutjesdijk \& Scholte, 2009), and math (Lane et al., 2005; Ledoux et al., 2012; Stoutjesdijk \& Scholte, 2009) than included students with SEBD. Other studies, in contrast, have shown equally low performance for both groups in reading
(Ledoux et al., 2012; Reid et al., 2004; Stoutjesdijk \& Scholte, 2009), spelling, and math (Reid et al., 2004). Again, it is not known how these groups functioned before placement choices were made, given that the role of academic functioning on placement choices has yet to be determined.

To know whether placement choices for students with SEBD are related to various aspects of student functioning, their behavioral, social, and academic functioning should be compared prospectively when they still reside in regular education without additional support-before placement in different kinds of schools. To our knowledge, such researchcombining behavioral, social, and academic functioning of students with SEBD before placement choices have been made-does not exist. One could expect, though, that students with SEBD who show the most severe problems in student functioning behaviorally, socially, and academically have more impact on class functioning than SEBD students with less severe problems. As they are the most difficult for teachers to instruct and support (Buttner, Pijl, Bijstra, \& Van den Bosch, 2016; Goei \& Kleijnen, 2009), this may result in placement in exclusive special education, whereas students with SEBD who show fewer problems in student functioning may be included in regular education with special education services.

\section{Teacher Factors}

Although aspects of student functioning have traditionally been deemed essential for placement choices (LCTI, 2006; Meijer, 2003), teachers may play an important role in placement choices as well (see work by Severson \& Walker, as cited in Gresham \& Kern, 2004). Teachers, for instance, find disruptive, rule-breaking behavior and problematic task-related behavior - characteristic of students with SEBD - the most difficult behaviors to deal with in the classroom (e.g., Buttner et al., 2016; Goei \& Kleijnen, 2009; Meijer, 2001). Relatedly, students with SEBD have generally more often been placed in restrictive educational settings than students with other special educational needs (Becker et al., 2011; De Greef \& Van Rijswijk, 2006). Because substantial differences exist between schools, and even between individual teachers, in their ability to handle students' disruptive behavior (Buttner et al., 2016; Furlong et al., 2004), it is important to also examine which teacher factors are related to placement choices for students with SEBD.

Two important teacher factors have been known to influence teachers' ability to deal with students' problem behavior. The first factor is teacher self-efficacy (Goei \& Kleijnen, 2009; Tsouloupas, Carson, Matthews, Grawitch, \& Barber, 2010) or "the extent to which a teacher believes that she or he can influence students' behavior and their academic achievement, especially of pupils with difficulties or those with particularly low learning motivation" (Friedman \& Kass, 2002, p. 675). The disruptive behavior of students with SEBD not only undermines the influence of teachers on their behavior and academic achievement, but it may also limit 
teacher influence on other students' behavior and achievement. Consequently, many teachers find it especially challenging to teach and support classrooms including students with SEBD (Goei \& Kleijnen, 2009). The question is whether teacher self-efficacy is also related to placement decisions. That is, are teachers with limited confidence in their ability to handle and teach students with SEBD more likely to refer students with SEBD to exclusive special education? Although various studies have shown that highly self-efficacious teachers were more tolerant toward problematic students (e.g., Tsouloupas et al., 2010; Zee \& Koomen, 2016), associations between teacher self-efficacy and placement choices have not been straightforward. Specifically, although older studies have suggested that highly self-efficacious teachers were less likely to refer problematic students to exclusive special education (e.g., Hughes, Barker, Kemenoff, \& Hart, 1993; Meijer \& Foster, 1988; Soodak \& Podell, 1993), more recent studies have found no associations between teacher self-efficacy and placement choices (e.g., Egyed \& Short, 2006; Gibbs \& Powell, 2012; Tejeda-Delgado, 2009). The second teacher factor is the attitudes a teacher has toward inclusive or exclusive education (Van der Veen, Smeets, \& Derriks, 2010) for students with special educational needs. Research has consistently shown that teachers who had more positive attitudes toward inclusive education were less likely to refer problematic students to exclusive special education (e.g., Avramidis \& Norwich, 2002; Meijer, 2001; Van der Veen et al., 2010).

\section{Self-Perceived Social-Emotional Functioning}

Although schools and parents jointly indicate that students with SEBD need additional support in school, we know surprisingly little about students' own perceptions of their social-emotional functioning and to what extent their perceptions are related to placement choices. Instead, the input for determining eligibility for additional support is mostly a shared effort of parents and schools. Although students' experiences have been considered critical aspects of their school development (Den Brok, Brekelmans, \& Wubbels, 2004), the self-perceived social-emotional experiences of students with SEBD in school have rarely been assessed within the context of placement choices. This raises the question whether students with SEBD themselves also experience that they have problems in social-emotional functioning as compared to typically developing peers, and if so, whether the extent to which they do is related to the placement choice that is made. When students with SEBD who will be included can already be distinguished from students who will be excluded based on their self-perceptions, self-perceptions might be an indicator for placement in either inclusive regular education or exclusive special education. This would highlight the use of self-reports, not only because students will be able to directly express their opinions (instead of indirectly via schools or parents), but also because self-reports could be useful instruments to inform future placement decisions in addition to schools' and parents' observations of the problems and subsequent needs of the student.
Research on self-perceived social-emotional functioning of students with SEBD in comparison with typically developing peers is scarce (Flower, McKenna, Haring, \& Pazey, 2015). Among typically developing children, behavior problems have mostly been related to elevated positive selfviews (David \& Kistner, 2000; Orobio de Castro, Brendgen, Van Boxtel, Vitaro, \& Schaepers, 2007). Children with behavior disorders, in contrast, have reported more negative selfviews than typically developing peers (Ekornås, Heimann, Tjus, Heyerdahl, \& Lundervold, 2011), and children with emotional disorders seem to hold even more negative self-perceptions than both typically developing peers (Chansky \& Kendall, 1997) and peers with behavior disorders (Ekornås et al., 2011). Furthermore, both students with a variety of special needs in regular education (e.g., internalizing/externalizing behavior problems, cognitive impairments, communication problems, and learning problems) and students with SEBD in exclusive special education report more negative social-emotional functioning than typically developing students (Ledoux et al., 2012). It is unknown, however, whether the self-perceived social-emotional functioning of students with SEBD differs between those who will later receive special education services in an inclusive classroom in regular education and those who will later be excluded and placed in exclusive special education.

\section{Present Study}

The literature review shows that there is some variability in results of studies examining behavioral, social, and academic functioning in students with SEBD included in regular education and in exclusive special education. This is because the studies differed in the questions they addressed (e.g., comparison of different student groups and different educational contexts), in their use of informants (i.e., parent-, teacher-, peer-, and self-reports), in the aspects of student functioning that they examined, and in their sample sizes. Therefore, it is difficult to reach conclusions about possible differences before placement between students with SEBD who will be included in regular education (i.e., included students with SEBD) and those who will be placed in exclusive special education (i.e., excluded students with SEBD). Clearly, a careful examination is needed of which aspects of student functioning and which teacher factors play a role. Moreover, research should simultaneously examine the behavioral, social, and academic functioning of students with SEBD and compare these aspects when both groups still reside in the same context of regular education (i.e., before placement choices have been made), instead of comparing groups of students with SEBD in one context (i.e., while receiving special education services in regular education) with groups of students with SEBD in a completely different context (i.e., having been placed in exclusive special education).

We conducted a descriptive multi-informant study in which we addressed two research goals. The first goal was to examine which aspects of student functioning and which 
teacher factors were related to placement choices for students with SEBD. To this end, we examined the two subgroups of included and excluded students with SEBD with respect to their behavioral, social, and academic functioning and the self-efficacy and attitudes toward inclusive education of their teachers before placement choices had been made. In selecting our teacher and student factors, we took an eclectic approach. That is, we combined standard Dutch practice guidelines for independent committees who determined eligibility for special education services with an evaluation of important factors as indicated by the literature.

For student functioning, we hypothesized, based on the majority of previous research, that included students with SEBD (i.e., who were included in regular education with special education services) would generally perform better behaviorally, socially, and academically than excluded students with SEBD (i.e., who were placed in exclusive special education) with the exception of reading, for which both groups were expected to perform equally. For teacher factors, we had less clear expectations. Older studies found that teachers with high self-efficacy were less likely to refer students with SEBD to exclusive special education (e.g., Hughes et al., 1993; Meijer \& Foster, 1988; Soodak \& Podell, 1993), but more recent studies did not find any associations between teacher self-efficacy and placement choices (e.g., Egyed \& Short, 2006; Gibbs \& Powell, 2012; Tejeda-Delgado, 2009). Therefore, the examination of this association was exploratory. For teacher attitudes toward inclusive education, we hypothesized that students with SEBD of teachers with more positive attitudes would be included in regular education, whereas students with SEBD of teachers with more negative attitudes would be placed in exclusive special education.

The second goal was to examine whether the two subgroups of included and excluded students with SEBD differed from typically developing peers in their self-perceptions of their social-emotional functioning to see if students experience multiple problems themselves and whether possible differences between groups of students were related to placement choices. The limited previous research on self-perceived social-emotional functioning of students with SEBD in comparison with typically developing peers suggests that students with SEBD would perceive their social-emotional functioning more negatively than typically developing students (e.g., Chansky \& Kendall, 1997; Ekornås et al., 2011). Because it is unknown, however, whether the self-perceived social-emotional functioning of students with SEBD differs between those who will later receive special education services in an inclusive classroom in regular education and those who will later be excluded and placed in exclusive special education, we set two opposing hypotheses. On the one hand, we hypothesized that students with SEBD would perceive their social-emotional functioning more negatively than typically developing students, whereas no differences between included and excluded students with SEBD were expected. Both subgroups of students with SEBD were assumed to have equally negative experiences while being in a regular education classroom without any additional support. On the other hand, we hypothesized that although both subgroups would report more negative social-emotional functioning than typically developing students, excluded students with SEBD would experience the most problems in social-emotional functioning and would therefore have even more negative self-perceptions than included students with SEBD.

\section{METHOD}

This was a cross-sectional study in which we included students with social, emotional, and behavioral difficulties (SEBD) applying for special education services who resided in regular education when participating in the study. That is, data were collected before eligibility for special education services was established. The study was approved by the research ethics committee of the Utrecht University Faculty of Social Sciences, in accordance with the Dutch regulations for research with children.

\section{Participants}

We included three subgroups of students in our study, all from schools for regular primary education located in northern $(n=36)$ and central $(n=19)$ parts of the Netherlands: (a) students with SEBD who would later receive special education services in inclusive classrooms in regular education (i.e., included students with SEBD; $n=45$ ), (b) students with SEBD who would be placed in exclusive special education (i.e., excluded students with SEBD; $n=17$ ), and (c) typically developing classmates $(n=772)$.

All included and excluded students with SEBD had previously or currently been in contact with one or more youth care institutions, and the majority $(98.4 \%)$ fulfilled established diagnostic criteria for Diagnostic and Statistical Manual of Mental Disorders (Fourth Edition, text revision) diagnoses (American Psychiatric Association, 2000), such as ASD (57.8\% and $64.7 \%$, respectively), ADHD (51.1\% and $29.4 \%$, respectively), and disruptive behavior disorders ( $4.4 \%$ and $11.8 \%$, respectively). Diagnoses were made by psychiatrists and psychologists from these youth care institutions. Typically developing classmates had no known history of any emotional or behavioral disorders in their school administration data.

Preliminary chi-square analyses and $t$ tests examining background variables showed that the group of included students with SEBD contained significantly more boys (84.4\%) than the group of typically developing students $(49.8 \%$ boys), whereas the group of excluded students with SEBD (70.6\% boys) did not significantly differ from either group, $\chi^{2}(2)=22.79, p<.001$, Cramer's $V=.167$. We found no differences between groups with respect to age $\left(M_{\text {included }}=8.69\right.$; $S D_{\text {included }}=1.00 ; M_{\text {excluded }}=8.53 ; S D_{\text {excluded }}=1.07 ; M_{\text {typically devel }-}$ oping $\left.=8.59 ; S D_{\text {typically developing }}=0.96\right)$ or ethnicity $(97.8 \%$ Dutch among included students with SEBD, 100\% Dutch among excluded students with SEBD, and 97.2\% Dutch among typically developing students). Additional chi-square analyses 
and $t$ tests on background variables for both groups of students with SEBD showed that included and excluded students with SEBD did not significantly differ from each other with respect to full-scale IQ $\left(M_{\text {included }}=100.47 ; S D_{\text {included }}=13.98\right.$; $\left.M_{\text {excluded }}=103.82 ; S D_{\text {excluded }}=12.79\right)$, diagnoses, comorbidity, or psychotropic medication use $(58.1 \%$ and $52.9 \%$ for included and excluded students with SEBD, respectively).

Participating teachers were teaching the students with SEBD at least 2 days a week for a period of 6 weeks or longer. The sex distribution was seven males and 46 females, ages ranged from 21 to 62 years old $(M=40.49, S D=12.64)$, and their mean years of experience in education was 17.24 (range $=1-44$ years).

\section{Procedure}

We recruited participants in collaboration with two independent committees who determined eligibility for additional support. These committees consist of members who have substantive expertise in the field of SEBD or education. When schools and parents of students with SEBD applied for eligibility for additional support at these institutions, parents were first asked to participate in our study. When parents agreed to participate, they returned a signed consent form, and we subsequently invited the schools of the students with SEBD to participate in our study.

When schools verbally consented to participate in (part of) the research, a school visit was planned. That is, the data were collected when the student with SEBD still resided in regular education without additional support, after parents and schools applied for additional support but before eligibility for additional support was established. Full participation entailed two parts, conducted by the first author or trained undergraduate and graduate students: (a) a classroom survey session with all children in the concerning class and their group teacher and (b) an individual testing session with the student with SEBD. In addition to that, we examined the application files of students with SEBD to collect data on their emotional and behavioral functioning and background variables (e.g., fullscale IQ and diagnoses). If full participation was too burdensome for either the student with SEBD or the teacher and the classroom, they discussed with the researchers in which part(s) they would be able to participate. Hence, not all data could be collected for all students.

Before the classroom surveys were conducted, the schools sent parents of classmates of the students with SEBD an informative letter in which parents were asked to give passive consent for their child to participate in the classroom survey as part of our study. Students whose parents declined participation and students who did not assent to participate did not complete any of the study's measures. Students with SEBD and their typically developing peers reported on their self-perceived social-emotional functioning and their peers' social status. Teachers reported on the work attitude of the student with SEBD, the student-teacher relationship with the student with SEBD, and on teacher self-efficacy and teacher attitudes toward inclusive education. Teacher factors were not measured for typically developing peers. After a short break, we individually tested the student with SEBD with three standardized school achievement tests (see Measures). If the students' fullscale IQ scores were not known from their application files, two subtests of an intelligence test (see Measures) were also conducted to estimate the full-scale IQ score. Aspects of student functioning were not measured for typically developing students because they did not have application files and they did not participate in individual testing sessions.

After data collection, independent committees determined whether students with SEBD were eligible for additional support. In the Netherlands, students with SEBD qualify to receive special education services for SEBD when they show severe emotional and behavioral problems at school and at home or in the community (either formally diagnosed or not), their participation in education is severely limited by their emotional and behavioral problems (i.e., they show impairments in learning or their interactions with school personnel or classmates), and the school's available support services are insufficient to meet the students' needs (LCTI, 2006; Meijer, 2003). The independent committees establish whether students with SEBD fulfill these criteria based on information on students' behavioral, social-emotional, and academic functioning provided by the schools (independent of the present research data). After eligibility for additional support was established, parents and schools agreed on the type of additional support to be provided: special education services in an inclusive classroom for regular education or placement in a school for exclusive special education. Based on these decisions, we retrospectively divided students with SEBD into two subgroups-included and excluded students with SEBD. With the inclusion of the typically developing peers, this resulted in three subgroups of students included in our study: (a) included students with SEBD, (b) excluded students with SEBD, and (c) typically developing peers. The flowchart in Figure 1 maps the steps taken from participant recruitment until final division into each subgroup.

\section{Measures}

We employed a cross-sectional multi-informant design. Students themselves, teachers, and peers reported on different aspects of the social-emotional, behavioral, and academic development of students with SEBD.

\section{Emotional and Behavioral Functioning}

We derived scores for children's behavior problems from the files that schools and parents composed to apply for eligibility for additional support with the independent committees. The independent committees used either the Teacher Report Form (TRF; Verhulst \& Van der Ende, 2013) or the Dutch Sociaal-Emotionele Vragenlijst (Social-Emotional Questionnaire [SEV]; Scholte \& Van der Ploeg, 2007) to measure behavior problems in school (see the Appendix for a more elaborate explanation of both questionnaires). Most 


\section{Figure 1. Flowchart of Recruitment Procedure and Inclusion and Exclusion of Participants}

\section{Recruitment and Inclusion}

Recruitment of students with SEBD in grade 2, 3 or 4 , when parents and schools applied for eligibility for additional support at independent committees $(n=239)$

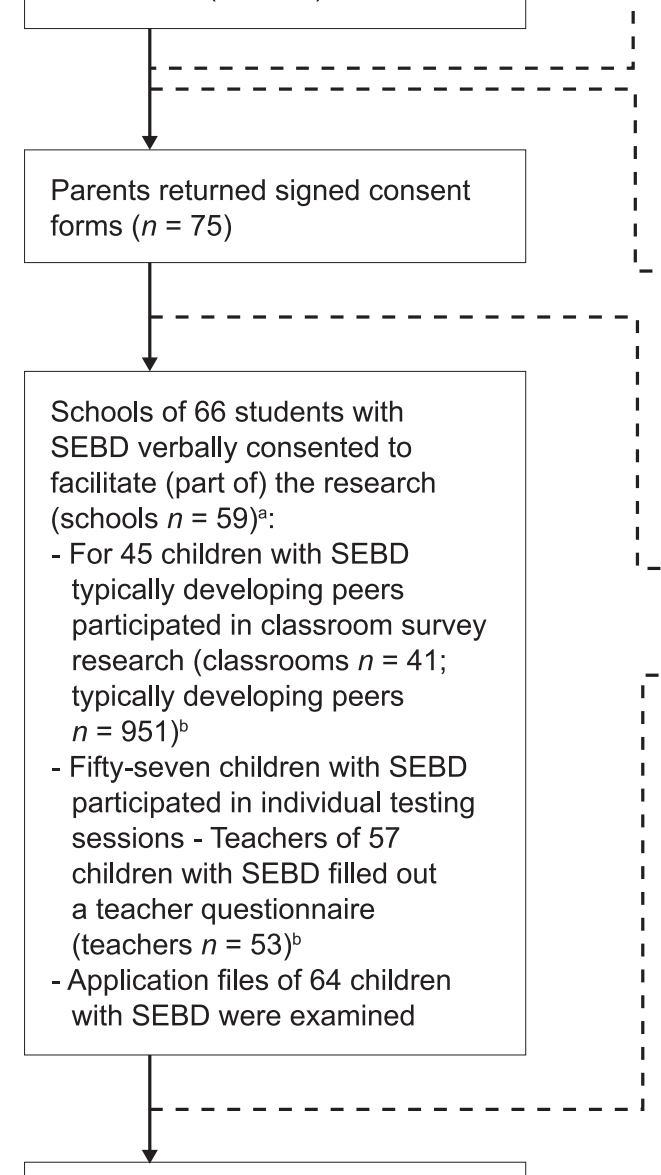

Independent committees determined eligibility for additional support for students with SEBD

\section{Decline and Exclusion}

Decline due to procedural factors $(n=55)$, such as: - application procedures for additional support ended before data collection could be set up $(n=26)$

- students did not meet study's inclusion criteria $(n=15)$

- students entered special education through residential care $(n=7)$

- parents were not approached because they experienced an overload of problems $(n=7)$

Parents declined $(n=109)$, due to:

- communication problems between parents $(n=4)$

- ending of the application procedure $(n=5)$

- participation being too burdensome $(n=31)$

- unknown reasons $(n=69)$

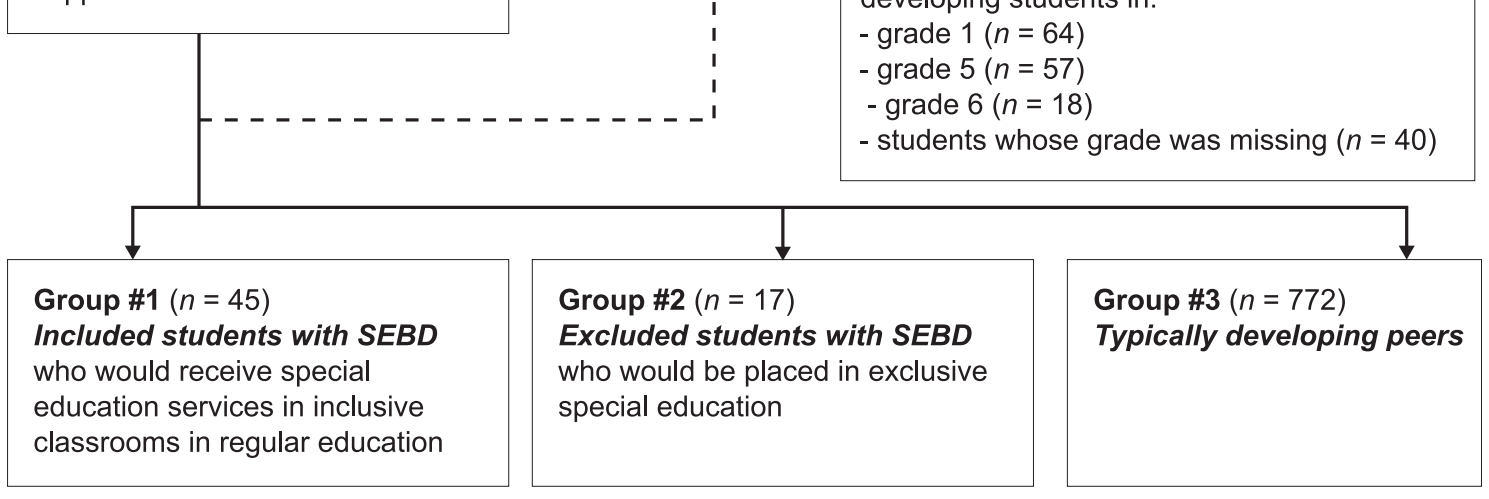

${ }^{a}$ Seven schools contained two students with social, emotional, and behavioral difficulties (SEBD) who participated in the study, resulting in a smaller sample for participating schools. ${ }^{b}$ Four classrooms contained two students with SEBD who participated in the study resulting in a smaller sample for participating classrooms and teachers. 
questionnaires (83.2\%) were filled out within 5 months of data collection. For a small group (16.8\%), the application procedure had to be extended anywhere from a few weeks to a few months; consequently, behavioral assessments were less recent.

Both questionnaires have evidenced reliability and validity among typically developing students and students with social-emotional problem behavior (Scholte \& Van der Ploeg, 2007; Tick, Van der Ende, \& Verhulst, 2007; Verhulst \& Van der Ende, 2013). Furthermore, validity of the TRF and reliability and validity of the SEV meet criteria of the Dutch Commissie Testaangelegenheden Nederland (Committee for Test Affairs [COTAN]; Evers, Lucassen, Meijer, \& Sijtsma, 2010). The TRF and SEV subscales that measure corresponding social-emotional problems have been shown to correlate with each other (Scholte \& Van der Ploeg, 2007). Students' application files thus contained data of different questionnaires. In addition, not all application files contained the raw TRF and SEV scores; however, most of them (91.9\%) contained classification scores. Both the TRF and SEV classify behavior according to three categories: normal (TRF percentiles 0-92; SEV percentiles 0-89), subclinical (TRF percentiles 93-96; SEV percentiles 90-94), and clinical behavior (TRF percentiles 97-100; SEV percentiles 95-100). Although the cutoff criteria differ slightly, we disregarded these small differences, as the subclinical and clinical categories concern extremely high percentiles in both cases. To accommodate the different sources of information, we created new classification scores on a 3 -point scale $(0=$ normal, $1=$ subclinical, $2=$ clinical) for internalizing behavior problems (based on the rounded average classification on corresponding TRF Anxious-Depressed and Withdrawn-Depressed subscales and SEV Anxiety, SEV Social Anxiety, and SEV AnxiousDepressed subscales), externalizing behavior problems (based on the rounded average classification on corresponding TRF Aggressive and Rule-Breaking subscales and SEV Oppositional-Defiant, Aggressive, and Antisocial subscales), and ADHD problems (based on the rounded average classification on the corresponding TRF Attention Problems subscale and SEV Attention-Deficit, Hyperactivity, and Impulsivity subscales).

\section{Social Functioning}

We measured student-teacher relationships with the teacher-reported Dutch Student-Teacher Relationship Scale, which has evidence of reliability and validity in research with a representative Dutch student population, including students with various special educational needs (Koomen, Verschueren, \& Pianta, 2007; Koomen, Verschueren, Van Schooten, Jak, \& Pianta, 2012), and in research of the COTAN (Evers et al., 2010). The Student-Teacher Relationship Scale consists of three dimensions: Closeness (11 items; e.g., "I share an affectionate, warm relationship with this child"), Conflict (11 items; e.g., "This child easily becomes angry with me"), and Dependency (six items; e.g., "This child needs to be continually confirmed by me"). Teachers had to rate on a 5-point scale (ranging from $1=$ definitely does not apply to $5=$ definitely applies) to what extent they thought each statement applied to their relationship with the student with SEBD. Cronbach's alpha coefficients ranged from .86 to .91 across scales, and Gutmann's lambda coefficients ranged from .87 to .91 across scales.

In addition, we measured peer-reported peer relationships with sociometric ratings (Cillessen, 2009), which have been shown to be reliable and valid in previous research with typically developing students (Maassen, Van Boxtel, \& Goossens, 2005; Maassen \& Verschueren, 2005). Furthermore, applicability of sociometric methods has been demonstrated in studies with children with emotional and behavioral problems as well (Breeman et al., 2015; Zakriski \& Prinstein, 2001). Students had to rate all their classmates individually on a 5-point Likert scale (ranging from $-2=$ not at all to $2=$ very much) with respect to how well they liked that particular student (acceptance/rejection) and how popular they perceived that particular student to be (perceived popularity). We set a minimum class participation rate of $60 \%$ to obtain acceptable sociometric scores (Marks, Babcock, Cillessen, \& Crick, 2013). We summed the scores received by each pupil. Because of the unequal number of pupils in the different classes, and because of the unequal number of scores of pupils within classes, these sum scores were converted into mean scores by dividing them by the number of raters (minus one because we disregarded self-scores in these measures). These final scores indicate how well liked and how popular participants are.

\section{Academic Functioning}

We measured task-related behavior with the teacherreported Conscientious Task Attitude subscale of the established Dutch Volginstrument Sociaal-Emotionele Ontwikkeling (Monitoring Instrument for Social-Emotional Development [VISEON]), which has reliability and validity evidence with typically developing students and students with special educational needs in elementary school (Cito, 2011; Citogroep, 2004) and according to the criteria of the COTAN (Evers et al., 2010). The Conscientious Task Attitude subscale consists of 11 items (e.g., "Student usually finishes tasks"), and teachers had to rate to what extent one of two opposing statements applied to the student with SEBD on a 4-point scale (ranging from $1=$ right statement definitely applies to 4 = left statement definitely applies). Cronbach's alpha and Guttman's lambda were both .93 .

Furthermore, we measured academic performance with established Dutch school achievement tests during individual testing sessions with students with SEBD. Reading ability was assessed with the Één-Minuut-Test (One-Minute Reading Fluency Test [EMT]; Brus \& Voeten, 2006). The test contains a word list with 116 words of increasing difficulty. The number of words that the participant is able to read within 1 minute is a measure of technical reading ability. Spelling ability was assessed with the PI-dictee (spelling dictation task; Geelhoed \& Reitsma, 2004). In this assessment, the 
researcher dictates a number of sentences and repeats the word that the participant has to write down. The test consists of 135 words of all spelling categories taught in elementary school. The words are grouped together in nine sets of 15 words each. Each set corresponds with an increasing amount of received spelling education. The number of correctly written words is a measure of spelling ability. Mathematics ability was assessed with the Tempo Test Automatiseren (Arithmetic Processing Speed Test [TTA]; De Vos, 2011). The test consists of four parts (addition, subtraction, multiplication, and division) with 50 sums of increasing difficulty. The participant has to calculate the answers without any aids. The number of sums that the participant is able to calculate within 2 minutes is a measure of processing speed of addition, subtraction, multiplication, and division. All school achievement tests have been shown reliable and valid with typically developing elementary school students (Brus \& Voeten, 2006; De Vos, 2011; Geelhoed \& Reitsma, 2004). Furthermore, reliability and validity evidence of the EMT and PI-dictee meet the criteria of the COTAN (Evers et al., 2010). Although the TTA has not been evaluated by the COTAN yet, children in Dutch elementary schools regularly take the TTA as a measure of early mathematics acquisition. We conducted all school achievement tests individually, and, for each skill, we looked up normative scores for children's individual scores in a table of normative data of students in the same grade.

\section{Teacher Factors}

We used an adjusted version of the Teacher Professional Capability Scale; evidence of reliability and validity has been shown in previous research (Friedman \& Kass, 2002). The Teacher Professional Capability Scale assesses teacher self-efficacy and consists of the subscales Classroom Context (19 items; e.g., "I think that my teaching is flexible and adaptive"), which measures teacher self-efficacy directly related to teaching and relationships with students, and School Context (11 items; e.g., "I have difficulty in making demands of the school administration"), which measures teacher self-efficacy related to participation in school activities and organizational politics. Teachers had to rate on a 6-point scale (ranging from $1=$ never to $6=$ always) to what extent they agreed with the statements. Cronbach's alpha coefficients were .91 for the Classroom Context and .79 for the School Context, and Guttman's lambda coefficients were .91 for the Classroom Context and .81 for the School Context.

To assess teacher attitudes toward inclusive education, we conducted an adjusted version of the Principals' Attitudes Toward Inclusive Education, which has been shown reliable and valid in previous research (Bailey, 2004; Bailey \& Du Plessis, 1998). We used four subscales: Teacher Workload and Management (five items; e.g., "Students with special needs will take up too much of the teachers' time"), which measures expected increases in main responsibilities due to inclusion; Inclusion Benefits and Level of Disability (six items; e.g., "Students with disabilities benefit academically from inclusion"), which measures equity views and appraisal of inclusion; Learning Challenges in Inclusive Education (seven items; e.g., "Students with severe speech difficulties should not be included in regular classrooms"), which measures functional challenges that students with disabilities present to teachers; and Excluded Students (three items; e.g., "Students who are continually aggressive toward school staff should not be included in regular classrooms"), which measures behaviors and disabilities that teachers find difficult to manage. Teachers had to rate on a 5-point scale (ranging from $1=$ strongly disagree to $5=$ strongly agree) to what extent they agreed with the statements. Cronbach's alpha coefficients ranged from .64 to .86 and Guttman's lambda coefficients ranged from .66 to .86 across scales.

\section{Self-Perceived Social-Emotional Functioning}

We measured self-perceived social-emotional functioning with the student-reported Dutch Student Perception of Affective Relationship with Teacher Scale (SPARTS; Koomen \& Jellesma, 2015) and the student-reported established Dutch VISEON (Cito, 2011; Citogroep, 2004). Reliability and validity evidence for the SPARTS comes from studies with typically developing elementary school students and students with internalizing problem behavior (Jellesma, Zee, \& Koomen, 2015; Koomen \& Jellesma, 2015; Zee \& De Bree, 2017). Reliability and validity evidence for VISEON also comes from research with typically developing elementary school students (Cito, 2011; Citogroep, 2004) and research of the COTAN (Evers et al., 2010). The SPARTS consists of the three dimensions: Closeness (eight items; e.g., "I tell my teacher things that are important to me"), Conflict (10 items; e.g., "I easily have quarrels with my teacher"), and Negative Expectations (seven items; e.g., "In the classroom my teacher doesn't know how I feel"). Students had to rate on a 5-point scale (ranging from $1=$ no, that is not true to $5=$ yes, that is true) to what extent they thought each statement applied to their relationship with the teacher. Both Cronbach's alpha coefficients and Guttman's lambda coefficients ranged from .65 to .75 across subscales. In addition, we used four VISEON subscales: Relationships With Peers (nine items; e.g., "When other children laugh, I think they laugh at me"), Task Attitude (nine items; e.g., "I pay attention during classes"), Self-Esteem (seven items; e.g., "I get good grades for tests"), and Attitudes Toward School (eight items; e.g., "I feel safe in this school"). Students had to rate on a 4-point scale (ranging from $1=$ not true to $4=$ true) to what extent the statements applied to them. Cronbach's alpha coefficients ranged from .73 to .80 , and Guttman's lambda coefficients ranged from .74 to .81 across subscales.

\section{Intelligence}

We obtained full-scale IQ scores from the application files in which intelligence was measured with established intelligence tests. For instance, Dutch versions of either the Wechsler Intelligence Scale for Children-III (Kort et al., 2005) or Wechsler Preschool and Primary Scale of Intelligence-III (Hendriksen \& Hurks, 2009) were used, both 
of which are suitable for use with typically developing children and children with various social-emotional problem behavior (Hendriksen \& Hurks, 2009; Kort et al., 2005) and recognized by the COTAN (Evers et al., 2010). If full-scale IQ was not known from a student's file, we conducted the subtests Block Design and Vocabulary of the Dutch version of the Wechsler Intelligence Scale for Children-III (Kort et al., 2005). Research has shown that this combination of Wechsler subtests is the most valid for estimating a child's cognitive capacities, even within a child psychiatric setting (Legerstee, Van der Reijden-Lakeman, Lechner-Van der Noort, \& Ferdinand, 2004).

\section{Data Analyses}

To analyze our data, we used informative hypothesis testing by means of inequality and equality constrained model selection (Mulder, Hoijtink, \& De Leeuw, 2012; Mulder, Hoijtink, \& Klugkist, 2010; Mulder et al., 2009), resulting in Bayes factors (BFs; Hoijtink, 2012). We used this statistical method for two reasons. First, with Bayesian statistics, we were able to directly test the amount of support for conflicting hypotheses derived from previous research. In that way, we were able to integrate the previous mixed findings with current results. Second, although studies examining students with SEBD have often been limited by small sample sizes (e.g., Becker et al., 2011; Farmer \& Hollowell, 1994; Lane et al., 2005), Bayesian statistics have provided possibilities to handle small samples with greater accuracy. We only provide a brief introduction of the statistical method that we used in this article because a full explanation is beyond the scope of our research. Interested readers are referred to Hoijtink (2012); Hoijtink, Klugkist, and Boelen (2008); and Van de Schoot, Hoijtink, et al. (2011) for a gentle introduction to Bayesian analyses and to Klugkist, Laudy, and Hoijtink (2005) for a more technical introduction.

With Bayesian inequality and equality constrained model selection, applied researchers can directly test the amount of support in favor of competing hypotheses that they derived from previous literature. First, each hypothesis has to be translated into a statistical model using inequality constraints on the means to specify the expected differences between the groups of students for each variable. We wanted to compare included and excluded students with SEBD, and we thus used a Bayesian alternative for the frequentist $t$ test. For aspects of student functioning, we hypothesized that included students with SEBD (i.e., who were included in regular education with special education services) generally performed better behaviorally, socially, and academically than excluded students with SEBD (i.e., who were placed in exclusive special education), except for reading, on which both groups were expected to perform equally - the "included performs better" hypothesis $\left(\mathrm{H}_{1}\right)$. We contrasted this hypothesis with a hypothesis in which both groups of students with SEBD were expected to perform equally - the "equal performance" hypothesis $\left(\mathrm{H}_{2}\right)$.
For teacher factors, we also wanted to compare included and excluded students with SEBD—again we used a Bayesian alternative for the frequentist $t$ test. Because previous research on self-efficacy has shown mixed findings, we examined the association between teacher self-efficacy and placement choices exploratorily. To this end we tested three conflicting hypotheses. The first hypothesis was that teachers of included students with SEBD would report higher self-efficacy than teachers of excluded students with SEBD — the "included performs better" hypothesis $\left(\mathrm{H}_{1}\right)$. The second hypothesis was that teachers of included and excluded students with SEBD would report similar self-efficacy levels - the "equal performance" hypothesis $\left(\mathrm{H}_{2}\right)$. Because the more recent studies showed no associations between teacher self-efficacy and placement choices, we did not want to exclude a third hypothesis in which we hypothesized that teachers of included students with SEBD would report lower self-efficacy than teachers of excluded students with SEBDthe "excluded performs better" hypothesis $\left(\mathrm{H}_{3}\right)$. For teacher attitudes toward inclusive education, we hypothesized that students with SEBD of teachers with more positive attitudes would be included in regular education, whereas students with SEBD of teachers with more negative attitudes would be placed in exclusive special education - the "included performs better" hypothesis $\left(\mathrm{H}_{1}\right)$. We contrasted this hypothesis with a hypothesis in which teachers of both groups of students with SEBD were expected to perform equally - the "equal performance" hypothesis $\left(\mathrm{H}_{2}\right)$.

For students' self-perceptions, we wanted to compare three student groups: included and excluded students with SEBD and typically developing peers. Therefore, we used a Bayesian alternative for a frequentist analysis of variance. Previous research suggested that students with SEBD would perceive their social-emotional functioning more negatively than typically developing students, but it was unknown whether the self-perceived social-emotional functioning of students with SEBD differs between those who will later receive special education services in an inclusive classroom in regular education and those who will later be excluded and placed in exclusive special education. As such, we formulated two opposing hypotheses. On the one hand, we hypothesized that students with SEBD would perceive their social-emotional functioning more negatively than typically developing students, whereas no differences between included and excluded students with SEBD were expected-the "typically developing performs better" hypothesis $\left(\mathrm{H}_{1}\right)$. On the other hand, we hypothesized that although both subgroups would report more negative social-emotional functioning than typically developing students, excluded students with SEBD would experience the most problems in social-emotional functioning and would therefore have even more negative self-perceptions than included students with SEBD - the "excluded performs worst" hypothesis $\left(\mathrm{H}_{2}\right)$. We contrasted both hypotheses with a third hypothesis in which we hypothesized that all three student groups would perform equallythe "equal performance" hypothesis $\left(\mathrm{H}_{3}\right)$. 
Before testing our hypotheses against each other, we first evaluated whether each hypothesis had a sufficient fit to the data by comparing each hypothesis against a hypothesis containing no constraints on the means of the groups of students, the so-called unconstrained hypothesis $\left(\mathrm{H}_{\mathrm{u}}\right)$. To what extent the data support one hypothesis over another is quantified by BFs. To compute these BFs, the software Bayesian Inequality and Equality Constrained Model Selection (BIEMS) requires a prior distribution of the parameters. Because all constrained models (i.e., the hypotheses that we specified based on the literature) are nested in the unconstrained model, BIEMS only needs a single prior under the unconstrained model, the so-called conjugate expected-constrained posterior prior (see Mulder et al., 2012). This implies that, by using the default settings of BIEMS, priors for each hypothesis have equal probabilities (see Klugkist et al., 2005, p. 493, Appendix C, Equation C3, for an explanation). In addition, BIEMS uses a very noninformative prior (i.e., objective prior; Mulder et al., 2012) by default, to refrain from adding subjective information to the analysis. A full explanation of the techniques used in the analyses is beyond the scope of our research. Interested readers are referred to Van de Schoot, Mulder, et al. (2011) for a gentle introduction to the evaluation of informative hypotheses and to Mulder et al. (2009) for a more technical introduction.

By using the software's default settings, we thus computed the relative support for each hypothesis based on the literature against the same "baseline" statistical model (i.e., the unconstrained model). When the BF is equal (or close to) 1 , both the specified (i.e., constrained) hypothesis and the unconstrained hypothesis receive an equal amount of support from the data. If $\mathrm{BF}>1$, then the specified hypothesis receives more support from the data (e.g., $\mathrm{BF}_{1 \mathrm{u}}=3$ indicates that Model 1 receives three times more support from the data than the unconstrained model). When $\mathrm{BF}<1$, the unconstrained hypothesis receives more support from the data (e.g., $\mathrm{BF}_{1 \mathrm{u}}=0.25$ indicates that Model 1 receives four times less support from the data than the unconstrained model). Some researchers use cutoff values of $\mathrm{BF}>3$ and $\mathrm{BF}>10$ to indicate substantial and strong evidence, respectively (Kass \& Raftery, 1995), but others argue strongly against using specific cutoff values for BF values to avoid what they call BF-hacking (also called P-hacking; see Konijn, Van de Schoot, Winter, \& Ferguson, 2015).

Thus, we first compared each hypothesis (i.e., $\mathrm{H}_{1}, \mathrm{H}_{2}$, and $\left.\mathrm{H}_{3}\right)$ against the unconstrained hypothesis $\left(\mathrm{H}_{\mathrm{u}}\right)$ to see whether the hypothesis was supported by the data at all. Next, we tested our specified hypotheses against each other. When multiple constrained hypotheses (reflecting conflicting theories) are considered, the amount of support for one hypothesis over another can be computed by dividing the BFs of the separate comparisons to the unconstrained hypotheses by each other. For student functioning, we first conducted 12 separate analyses for each aspect of students' behavioral, social, and academic functioning. Subsequently, we entered all aspects of student functioning into one overall analysis to compare the amount of support for each overall hypothesis (i.e., all inequality- and equality-constrained hypotheses of a single model at once) with the unconstrained hypothesis. Lastly, we computed the BFs of each specified hypothesis compared to each other hypothesis to see which hypothesis was most supported by the data. For teacher factors, we only conducted six separate analyses for each teacher factor to compare the amount of support for each hypothesis with the unconstrained hypothesis and with each other. Due to mixed findings in the literature for self-efficacy, we could not specify overall hypotheses for teacher factors. For self-perceived social-emotional functioning, we first conducted seven separate analyses for each aspect of self-perceived social-emotional functioning. Subsequently, we entered all aspects of self-perceived social-emotional functioning into one analysis to compare the amount of support for each overall hypothesis with the unconstrained hypothesis. Lastly, we computed the BFs of each specified hypothesis compared to each other hypothesis to see which hypothesis was most supported by the data.

\section{RESULTS}

To analyze our data, we used BIEMS (Mulder et al., 2009, 2010, 2012), which resulted in BFs for each hypothesis. Consequently, we compared the amount of support for each hypothesis to each other.

\section{Student Functioning}

Results showed that for all aspects of student functioning the "equal performance" hypothesis received more support from the data than the unconstrained hypothesis and the "included performs better" hypothesis (see Table 1). Although the BFs of the constrained hypotheses and the hypothesis comparisons were reasonably low, the results seem to suggest that included and excluded students with SEBD generally do not differ in student functioning.

However, when we at once entered all aspects of student functioning in the "equal performance" hypothesis and "included performs better" hypothesis, respectively (see last row of Table 1), the BFs of both constrained hypotheses dropped below 1 . This indicates that although the results of each separate analysis pointed toward the "equal performance" hypothesis, the data of our small samples of included and excluded students with SEBD could not provide support for our complex "equal performance" and "included performs better" hypotheses, in which we considered all aspects of behavioral, social, and academic functioning at once. Therefore, differences in BFs for separate aspects of student functioning should be interpreted with caution.

\section{Teacher Factors}

Results for teacher self-efficacy depended on the specific context of self-efficacy. That is, for self-efficacy in the classroom context, the "excluded performs better" hypothesis received more support from the data than the other hypotheses. 


\section{Table 1. Descriptive Statistics for Behavior Problems, Social Relationships, Task-Related Behavior, and School Achievement for Both Subsamples of Students With SEBD}

\begin{tabular}{|c|c|c|c|c|c|c|c|}
\hline \multirow[b]{2}{*}{ Variable } & \multicolumn{2}{|c|}{$\begin{array}{c}\text { Included } \\
\text { Students With } \\
\text { SEBD }(n=45)\end{array}$} & \multicolumn{2}{|c|}{$\begin{array}{c}\text { Excluded } \\
\text { Students With } \\
\text { SEBD }(n=17)\end{array}$} & \multirow{2}{*}{$\begin{array}{c}\begin{array}{c}\mathrm{H}_{1}: \text { Included } \\
\text { Performs Better } \\
\text { Hypothesis }\end{array} \\
\mathrm{BF}_{1 \mathrm{u}}\end{array}$} & \multirow{2}{*}{$\begin{array}{c}\begin{array}{c}\mathrm{H}_{2}: \text { Equal } \\
\text { Performance } \\
\text { Hypothesis }\end{array} \\
\mathrm{BF}_{2 \mathrm{u}}\end{array}$} & \multirow{2}{*}{$\begin{array}{c}\text { Hypothesis } \\
\text { Comparison }\end{array}$} \\
\hline & $M^{a}$ & $S D^{\mathrm{a}}$ & $M^{a}$ & $S D^{\mathrm{a}}$ & & & \\
\hline Internalizing Behavior Problems & 1.21 & 0.95 & 1.27 & 0.96 & 1.14 & 3.00 & $3.00 / 1.14=2.63$ \\
\hline Externalizing Behavior Problems & 1.21 & 0.84 & 1.27 & 0.88 & 1.08 & 2.79 & $2.79 / 1.08=2.58$ \\
\hline ADHD Symptoms & 1.09 & 0.97 & 1.20 & 0.94 & 1.30 & 2.82 & $2.82 / 1.30=2.17$ \\
\hline Closeness (Teacher-Reported) & 3.72 & 0.73 & 3.98 & 0.88 & 0.34 & 1.46 & $1.46 / 0.34=4.29$ \\
\hline Conflict (Teacher-Reported) & 2.45 & 0.91 & 2.36 & 1.02 & 0.78 & 2.26 & $2.26 / 0.78=2.90$ \\
\hline Dependency & 2.89 & 1.07 & 2.96 & 0.84 & 1.18 & 2.30 & $2.30 / 1.18=1.95$ \\
\hline Social Preference ${ }^{b}$ & 0.20 & 0.65 & 0.23 & 0.76 & 0.91 & 2.16 & $2.16 / 0.91=2.37$ \\
\hline Popularity ${ }^{b}$ & -0.63 & 0.43 & -0.47 & 0.49 & 0.42 & 1.49 & $1.49 / 0.42=3.55$ \\
\hline Task Attitude (Teacher-Reported) & 2.22 & 0.72 & 1.96 & 0.94 & 1.66 & 1.68 & $1.68 / 1.66=1.01$ \\
\hline Reading Achievement $^{d}$ & 8.65 & 3.53 & 9.17 & 3.43 & $N / A$ & $1.97^{\circ}$ & \\
\hline Spelling Achievement ${ }^{d}$ & 17.80 & 22.82 & 13.77 & 23.04 & 1.40 & 1.82 & $1.82 / 1.40=1.30$ \\
\hline Math Achievement ${ }^{d}$ & 25.40 & 22.54 & 25.08 & 22.92 & 1.03 & 2.20 & $2.20 / 1.03=2.14$ \\
\hline Total $(n=38)$ & & & & & $0.25^{\mathrm{e}}$ & 0.32 & $0.32 / 0.25=1.28$ \\
\hline
\end{tabular}

Note. Asymptotic significances are presented. $\mathrm{H}=$ Hypothesis; $\mathrm{BF}=$ Bayes factor; ${ }_{\mathrm{u}}=$ unconstrained hypothesis; $\mathrm{ADHD}=$ attention deficit hyperactivity disorder; $\mathrm{N} / \mathrm{A}=$ not applicable.

${ }^{a}$ Posterior sample means and variances can be found in the Appendix. ${ }^{b}$ Some students with SEBD were individually tested only, because the school could not facilitate a classroom testing session, resulting in lower sample sizes for peer-rated acceptance and popularity. ${ }^{\mathrm{C}}$ Because we expected equal performance for reading in both hypotheses, only one hypothesis $\left(\mu_{1}=\mu_{2}\right)$ was tested against the unconstrained hypothesis. ${ }^{d}$ Some students with SEBD participated in classroom testing sessions only (i.e., individual testing sessions with an unfamiliar experimenter would be too stressful), resulting in lower sample sizes for reading, spelling, and math achievement. " In the total "included performs better" hypothesis, included students are hypothesized to perform better, except for reading, on which both groups perform equally.

For teacher self-efficacy in the school context, in contrast, the "equal performance" hypothesis received more support from the data than the other hypotheses (see Table 2). Although the BFs of the constrained hypotheses and the hypotheses comparisons were reasonably low, the results seem to suggest that teachers with higher self-efficacy in the classroom context (i.e., "the sense of professional efficacy pertaining to teaching, educating and motivating students, as well as controlling inter-relations with students," Friedman \& Kass, 2002, p. 681) were more likely to refer students with SEBD to exclusive special education as compared to teachers with lower self-efficacy in the classroom context. Teacher self-efficacy in the school context (i.e., "involvement in school activities, participation in decision-making and influencing school organizational politics," p. 681), however, did not seem to be related to placement choices for students with SEBD.

For teacher attitudes toward inclusive education, results showed that the "included performs better" hypothesis generally received more support from the data than the unconstrained hypothesis and the "equal performance" hypothesis, except for the subscale Learning Challenges in Inclusive Education, for which the "equal performance" hypothesis received more support from the data than other hypotheses (see Table 2). Although the BFs of the constrained hypotheses and the hypothesis comparisons were reasonably low, the results seem to suggest that teachers with generally more positive attitudes toward inclusive education were more likely to include students with SEBD in regular education with special education services as compared to teachers with generally less positive attitudes toward inclusive education. Teacher attitudes toward learning challenges in inclusive education, however, did not seem to be related to placement choices for students with SEBD.

\section{Self-Perceived Social-Emotional Functioning}

Results showed that for all aspects of self-perceived social-emotional functioning, the "typically developing performs best" hypothesis received more support from the data than the unconstrained hypothesis, the "equal performance" 


\section{Table 2. Descriptive Statistics for Teacher Self-Efficacy and Teacher Attitudes Toward Inclusive Education for Included and Excluded Students With SEBD}

\begin{tabular}{|c|c|c|c|c|c|c|c|c|}
\hline \multirow[b]{2}{*}{ Variable } & \multicolumn{2}{|c|}{$\begin{array}{c}\text { Included } \\
\text { Students With } \\
\text { SEBD }(n=45)\end{array}$} & \multicolumn{2}{|c|}{$\begin{array}{c}\text { Excluded } \\
\text { Students With } \\
\text { SEBD }(n=17)\end{array}$} & \multirow{2}{*}{$\begin{array}{c}\mathrm{H}_{1} \text { : Included } \\
\begin{array}{c}\text { Performs Better } \\
\text { Hypothesis }\end{array} \\
\mathrm{BF}_{1 \mathrm{u}}\end{array}$} & \multirow{2}{*}{$\begin{array}{c}\begin{array}{c}\mathrm{H}_{2}: \text { Equal } \\
\text { Performance } \\
\text { Hypothesis }\end{array} \\
\mathrm{BF}_{2 \mathrm{u}}\end{array}$} & \multirow{2}{*}{$\begin{array}{c}\begin{array}{c}\mathrm{H}_{3}: \text { Excluded } \\
\text { Performs Better } \\
\text { Hypothesis }\end{array} \\
\mathrm{BF}_{3 \mathrm{u}}\end{array}$} & \multirow{2}{*}{$\begin{array}{c}\begin{array}{c}\text { Hypothesis } \\
\text { Comparison }\end{array} \\
\text { BF }\end{array}$} \\
\hline & $M^{a}$ & $S D^{\mathrm{a}}$ & $M^{\mathrm{a}}$ & $S D^{\mathrm{a}}$ & & & & \\
\hline Class & 4.77 & 0.49 & 5.05 & 0.34 & 0.10 & 0.59 & 1.91 & $\begin{array}{l}\mathrm{BF}_{32} 1.91 / 0.59=3.24 \\
\mathrm{BF}_{31} 1.91 / 0.10=19.10\end{array}$ \\
\hline School & 4.74 & 0.53 & 4.87 & 0.41 & 0.45 & 1.72 & 1.54 & $\begin{array}{l}\mathrm{BF}_{21} 1.72 / 0.45=3.82 \\
\mathrm{BF}_{23} 1.72 / 1.54=1.12\end{array}$ \\
\hline Workload & 2.79 & 0.79 & 2.48 & 0.62 & 1.76 & 1.13 & $\mathrm{~N} / \mathrm{A}$ & $\mathrm{BF}_{12} 1.76 / 1.13=1.56$ \\
\hline Benefits & 3.61 & 0.50 & 3.33 & 0.49 & 1.87 & 0.66 & $\mathrm{~N} / \mathrm{A}$ & $\mathrm{BF}_{12} 1.87 / 0.66=2.83$ \\
\hline Challenges & 3.26 & 0.68 & 3.21 & 0.47 & 1.17 & 2.15 & $N / A$ & $\mathrm{BF}_{12} 1.17 / 2.15=0.54$ \\
\hline Excluded & 2.11 & 0.69 & 1.67 & 0.41 & 1.93 & 0.35 & $\mathrm{~N} / \mathrm{A}$ & $\mathrm{BF}_{12} 1.93 / 0.35=5.51$ \\
\hline
\end{tabular}

Note. Asymptotic significances are presented. BF=Bayes factor; ${ }_{\mathrm{u}}=$ unconstrained hypothesis; Class=teacher self-efficacy in the classroom context; School=teacher self-efficacy in the school context; Workload=teacher workload and management; Benefits=inclusion benefits and level of disability; Challenges =learning challenges in inclusive education; Excluded=excluded students; N/A = not applicable.

${ }^{a}$ Posterior sample means and variances can be found in the Appendix.

hypothesis, and the "excluded performs worst" hypothesis (see Table 3). Although the BFs of the "equal performance" hypotheses were almost 0 and the BFs of the "excluded performs worst" hypotheses were reasonably low, the BFs of the "typically developing performs best" hypotheses were quite substantial, which suggests that although included and excluded students with SEBD do not differ in self-perceived social-emotional functioning, they perceive their social-emotional functioning more negatively than typically developing peers.

However, when at once all aspects of self-perceived social-emotional functioning were entered as an overall "equal performance" hypothesis, "typically developing performs best" hypothesis, and "excluded performs worst" hypothesis, respectively (see last row of Table 3), the BFs of both the "typically developing performs best" hypothesis and the "excluded performs worst" hypothesis tremendously increased. This indicates that both constrained hypotheses are strongly supported by the data. Even though the BF of the hypothesis comparison between the "typically developing performs best" and "excluded performs worst" hypotheses is reasonably low, the results convincingly indicate that students with SEBD have more negative self-perceptions about their social-emotional functioning than typically developing students, whereas both subgroups of students with SEBD do not differ in their self-perceived social-emotional functioning.

\section{DISCUSSION}

Although placement choices are deemed important for the development of students with SEBD, it is unclear which factors are related to placement choices for inclusive or exclusive education of these students. Results of our study show that students with SEBD who are included in regular education and those who are placed in special education seem similar in all aspects of student functioning. In contrast, both subgroups seem to differ in several characteristics of their teachers: Teachers of students who were later included in regular education reported lower teacher self-efficacy in the classroom context and more positive attitudes toward inclusive education than teachers of students who were later placed in exclusive special education. Furthermore, students with SEBD perceived their social-emotional functioning more negatively than typically developing students, whereas included and excluded students with SEBD did not differ in their self-perceptions.

Surprisingly, aspects of student functioning were not related to placement choices for students with SEBD. This contrasts with most previous research that indicated that included students with SEBD perform better in various developmental areas than students with SEBD who were placed in exclusive special education (Bijstra, 2004; Drost \& Bijstra, 2008; Lane et al., 2005; Ledoux et al., 2012; Stoutjesdijk \& Scholte, 2009; Stoutjesdijk et al., 2012). An explanation for these findings might be that students who experienced more severe problems and who consequently might have been placed in exclusive special education more often declined participation in our study. For instance, parents and schools who declined participation often indicated that participation would be too burdensome for their child. This may partly explain the fact that we did not find any evidence that student functioning was related to placement choices. 


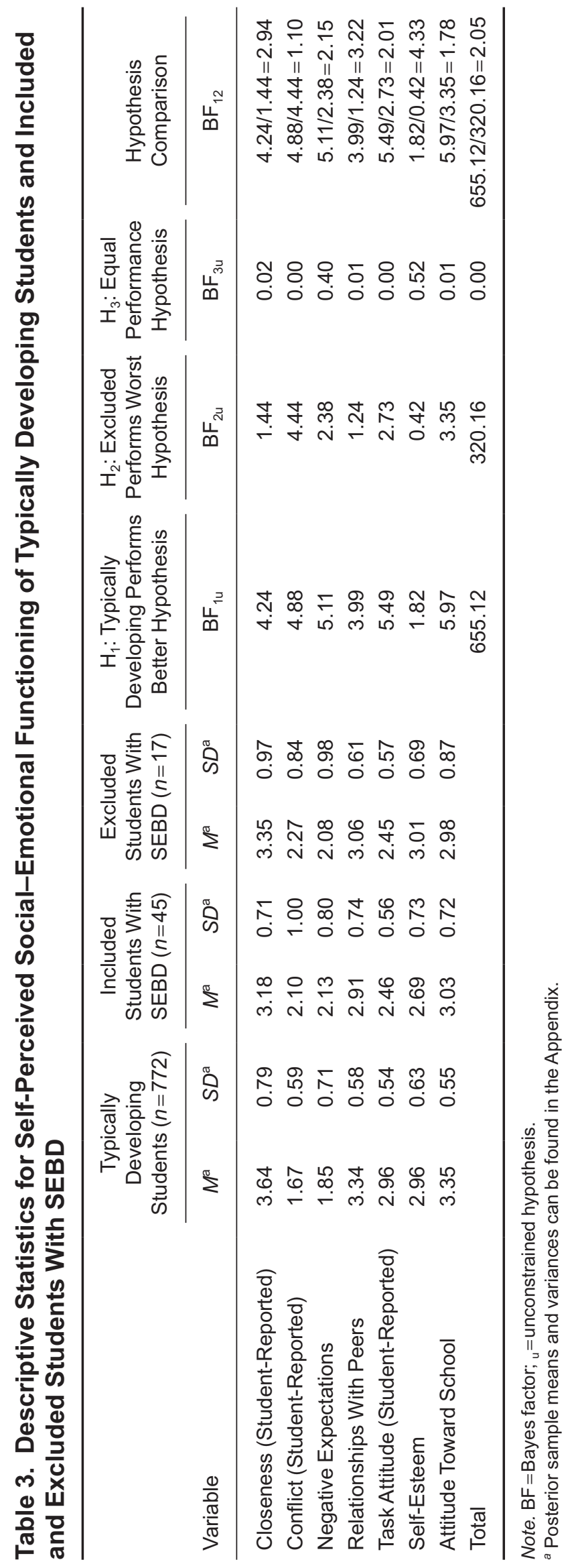

However, the finding that student functioning is not a major determining factor in placement choices for students with SEBD in a possibly selective sample with less severe SEBD problems is informative by itself. For these studentswho do fulfill the eligibility criteria for special education services but have relatively less severe problems-placement choices might have been less clear from the start, and our findings may specifically hold for this group. Although students with SEBD showing extreme problems in student functioning might be placed in exclusive special education more often (e.g., Bijstra, 2004), we hypothesize that for those students with SEBD who have relatively less severe problems, aspects of student functioning did not seem to be a determining factor for either type of placement and teacher factors might have played a more important role.

Teachers who later included students with SEBD in their regular classrooms reported lower self-efficacy in the classroom context than teachers who later referred students with SEBD to exclusive special education. Teachers did not differ in self-efficacy in the school context. These results are in contrast with previous studies which either showed that higher teacher self-efficacy was associated with fewer referrals to exclusive special education (e.g., Hughes et al., 1993; Meijer \& Foster, 1988; Soodak \& Podell, 1993) or that teacher self-efficacy and referral rates were not related (e.g., Egyed \& Short, 2006; Gibbs \& Powell, 2012; Tejeda-Delgado, 2009). Given that teachers find the problem behaviors of students with SEBD the most difficult behaviors to deal with in the classroom (Goei \& Kleijnen, 2009; Meijer, 2001), we speculate that teachers with high self-efficacy (i.e., who feel confident in their own skills to educate, motivate, and support students) might realize that the student needs more support than he or she can provide in the regular classroom, resulting in referral to exclusive special education. Teachers with low self-efficacy, in contrast, may question their own abilities more and might feel the need to try harder or to search for more support within their school. Because teachers are predominantly confronted with disruptive behavior of students with SEBD in the classroom context (e.g., Goei \& Kleijnen, 2009), it seems reasonable that differences in teacher self-efficacy were found in the classroom context only.

Placement choices for students with SEBD were also related to teachers' attitudes toward inclusive education. Teachers who included students with SEBD in their regular classrooms experienced a smaller increase in workload due to inclusion than teachers who referred students with SEBD to exclusive special education; they also had stronger equity views and perceived more benefits of inclusion. This is in line with previous research and lends support to the assumption that teachers with more positive attitudes toward inclusion are more likely to deal with the special educational needs of students with SEBD in the regular education context (Avramidis \& Norwich, 2002; Meijer, 2001; Van der Veen et al., 2010). This might also relate to research that finds that teachers in regular education often perceive themselves not to be adequately prepared to teach students with 
special educational needs in their classrooms (Solis, Vaughn, Swanson, \& McCulley, 2012). Teachers of both groups did not differ in their attitudes regarding the practical problems that students with disabilities present to teachers (e.g., classroom accessibility for students with physical disabilities and alternative communication for students with hearing disabilities). We hypothesize that this finding may suggest that practical problems present more generally perceived objective challenges to teachers (i.e., "evaluations in the professional sphere of responsibility", see Bailey, 2004, p. 78), whereas workload and equity views may reflect teachers' individually varying subjective experiences to a higher extent (i.e., "personal attitudes," see Bailey, 2004, p. 78).

The self-perceived social-emotional functioning of students differed between typically developing students and students with SEBD: When they resided in regular education classrooms without additional support, students with SEBD perceived their social-emotional functioning more negatively than typically developing students. This is consistent with previous research (Chansky \& Kendall, 1997; Ekornås et al., 2011) and indicates that students with SEBD—like their parents and teachers-detect problems in their socialemotional functioning themselves. Students' self-perceptions were, however, not related to placement choices: Included and excluded students with SEBD held equally negative self-perceptions of their social-emotional functioning. We hypothesize that irrespective of later inclusion or placement in exclusive special education, before placement choices are made, both subgroups acknowledge that they do not function well, which seems to confirm their need for additional support.

\section{Strengths, Limitations, and Implications for Practice}

This study contributes to the literature in several ways. First, we showed in which ways students with SEBD, who were retrospectively divided in two subgroups of included and excluded students, were similar or different before placement choices had been made. Second, we used multi-informant data and integrated various domains of student functioning (i.e., behavioral, social, and academic), whereas previous studies often used fewer informants and examined fewer domains. Third, we combined student characteristics (i.e., aspects of student functioning) and contextual characteristics (i.e., teacher factors) when examining the relationships with placement choices for students with SEBD. Fourth, we investigated self-perceptions of students with SEBD, which is rarely done among this population. Last, the use of innovative Bayesian statistical procedures allowed us to test to what extent our data supported conflicting hypotheses based on mixed findings in the literature. Therefore, we were able to draw preliminary conclusions based on a relatively small sample from a special population.

With a small sample size, caution must be applied, as the BFs for our separate analyses of student functioning and teacher factors were low. This indicates only weak support in favor of the hypotheses under consideration. When all student functioning variables were simultaneously considered in a single, more complex hypothesis, the data did not support the respective hypothesis anymore. More research with larger samples needs to be undertaken to uncover hypotheses that receive substantial support of the data over other hypotheses and to rule out unconsidered hypotheses, weak data, or other explanations; however, the results of the current study may be used to direct future research questions in this field. In addition, we were not able to examine school-level factors, whereas school-level factors like school systems, administrative support, school policies, school size, school attractiveness and facilities, the implementation of schoolwide programs, the presence or lack of the implementation of evidence-based practices, and the proportion of students with special educational needs in a school could play a direct role or indirect role (e.g., by influencing teachers' self-efficacy and attitudes toward inclusive education) in placement decisions. Consequently, the conclusions that can be drawn about teacher factors are limited.

Furthermore, our study is limited by several methodological concerns. We used several measures that have only been validated by the authors of the instrument instead of by multiple sources, the Principals' Attitudes Toward Inclusive Education has not yet been validated for use among teachers, the norms of some of our measures were outdated (e.g., EMT and PI-dictee), our Excluded Students and Negative Expectations subscales showed insufficient reliability, and the use of our newly created classification scores based on TRF and SEV classification scores was not validated by procedural or psychometric studies. Furthermore, although we used the most reliable and validated self-report measures of the constructs we studied, there is little research on the psychometric qualities of self-report measures with students with SEBD. Directions for future research would therefore be to develop high-quality measurement tools for research and practice that have been experimentally validated for use among students with SEBD and, when these are lacking, to sufficiently address how these issues related to reliability and validity limit the study's findings.

Finally, the generalizability of our findings was limited by the restricted region where data was collected (i.e., only northern and central parts of the Netherlands participated), sex effects (i.e., a limited number of participating girls), ethnicity effects (i.e., a limited number of participants of various backgrounds), and selection effects (i.e., a relatively high nonparticipation rate, suggesting that the students who experienced the most severe problems in multiple areas declined). Furthermore, we could not examine the representativeness of our study sample because we did not have any data on the nonparticipating students with SEBD. In addition, from an international perspective, the eligibility criteria for special education services in the Netherlands differ from those in the United States. For instance, in the United States, students whose emotional and behavioral problems can be explained by other conditions or specific developmental disorders, such 
as ASD or CD, do not automatically fulfill the requirements for eligibility for placement. In the Netherlands, however, the additional exclusion criteria are less strict, which leads to the inclusion of students with comorbid disorders (e.g., ASD or CD) and students who have been involved in the justice system in the SEBD population in the Netherlands and not in the United States. Although one could expect significant overlap between populations due to the severe common problems that students with SEBD face across countries (e.g., Breeman et al., 2015; Cannon et al., 2013; Lynn, Carroll, Houghton, \& Cobham, 2013; Wagner, Kutash, Duchnowski, Epstein, \& Sumi, 2005), the differences may prevent direct comparisons between students with EBD in the United States and students with SEBD in the Netherlands, for example. Future research would benefit from a more in-depth consideration of variations across sexes, ethnicities, countries, and geographical regions in larger samples.

Despite the limitations, our findings suggest that, at least for students with SEBD who fulfill the criteria for additional support but who might not show the most severe problems in student functioning, aspects of student functioning may not be determining factors in placement choices, whereas teacher factors do seem to play a role. This indicates that we might need to focus not only on student functioning but also on how teacher factors - and relatedly, school factors - may influence placement choices. To this end, we might need different or additional measures to examine which school and teacher factors play an important role in the management of disruptive behavior in the classroom, before students need to apply for special education services. School and teacher factors might be at play in any situation in which student disruptive behavior is considered unmanageable. If certain school and teacher factors play a role, schools and teachers may possibly try to alter these factors with evidence-based methods first.

Moreover, as teachers in regular education often do not perceive themselves to be adequately prepared to teach students with special educational needs in their classrooms (Solis et al., 2012), another step to take first might be to support these teachers in school. Specifically, teachers might be supported to adequately assess various aspects of student functioning and to evaluate to what extent their own personal beliefs might play a role in monitoring and managing students with SEBD in the classroom. By effectively supporting these teachers, they might acquire both skills to better manage disruptive student behavior in the classroom and to better evaluate which students can be supported in inclusive regular education and which students may benefit more from exclusive special education. Ways to effectively support teachers might be to have specialists (e.g., special education teachers and school psychologists) coordinate curriculum changes such as the use of alternative grouping in pairs or small groups to facilitate learning in the classroom (Solis et al., 2012); to use highly valued and effective methods for professional development such as coaching on the job, peer supervision, and consulting colleagues (Bruggink,
2015; Inspectorate of Education, 2013; Walraven, Kieft, \& Broekman, 2011); and to facilitate teachers in time for communication and planning with their direct colleagues (Solis et al., 2012). Combined with findings on the development of students in different educational settings, our findings may also contribute to the development of clear guidelines to inform future placement choice processes. Longitudinal research will be needed to examine if specific factors can be distinguished that predict the development of students with SEBD in both educational settings.

Furthermore, our study showed that students with SEBD, like their parents and teachers, experience problems in their social-emotional functioning. This indicates that students with emotional and behavioral problems do acknowledge problems in social-emotional functioning in school. Self-reported screening instruments could thus be used to identify students at risk, and the school monitoring systems that schools are obliged to use to follow student development in various areas can conveniently be used to identify these vulnerable students. Although self-perceptions were not related to placement choices, future research examining self-perceptions of students with SEBD in settings for both inclusive regular education and exclusive special education may shed more light on students' self-perceived social-emotional development after they have received a certain amount of special education services.

\section{APPENDIX. DESCRIPTION OF THE TRF AND THE SEV}

The Teacher Report Form (TRF; Verhulst \& Van der Ende, 2013) is a behavioral questionnaire to measure problem behavior and skills of children and youth aged 6-18 years. The TRF contains 120 items concerning social, emotional, and behavioral problems. The TRF contains 10 narrow-band scales: Anxious/Depressed (16 items; e.g., "often cries"); Withdrawn/Depressed (eight items; e.g., "won't talk"); Somatic Complaints (nine items; e.g., "feels tired without particular reason"); Social Problems (11 items; e.g., "does not get along with other students"); Thinking Problems (10 items; e.g., "has strange ideas"); and Attention Problems (26 items; e.g., "acts young for his/ her age"), consisting of specific subscales Attention Deficit (14 items) and Hyperactivity-Impulsivity (12 items); RuleBreaking Behavior (12 items; e.g., "breaks school rules"); and Aggressive Behavior (20 items; e.g., "argues a lot"). In addition, three broadband scales are distinguished: Internalizing (consisting of scores on items of Anxious/ Depressed, Withdrawn/Depressed, and Somatic Complaints scales), Externalizing (consisting of scores on items of RuleBreaking Behavior and Aggressive Behavior scales), and Total Problems (sum of all problems). Teachers had to rate on a 3-point scale (ranging from $0=$ not at all [as far as $I$ know] to $2=$ clearly or often) to what extent the statement applied to the student with SEBD based on the functioning of the student in the past 2 months. Students' scores 


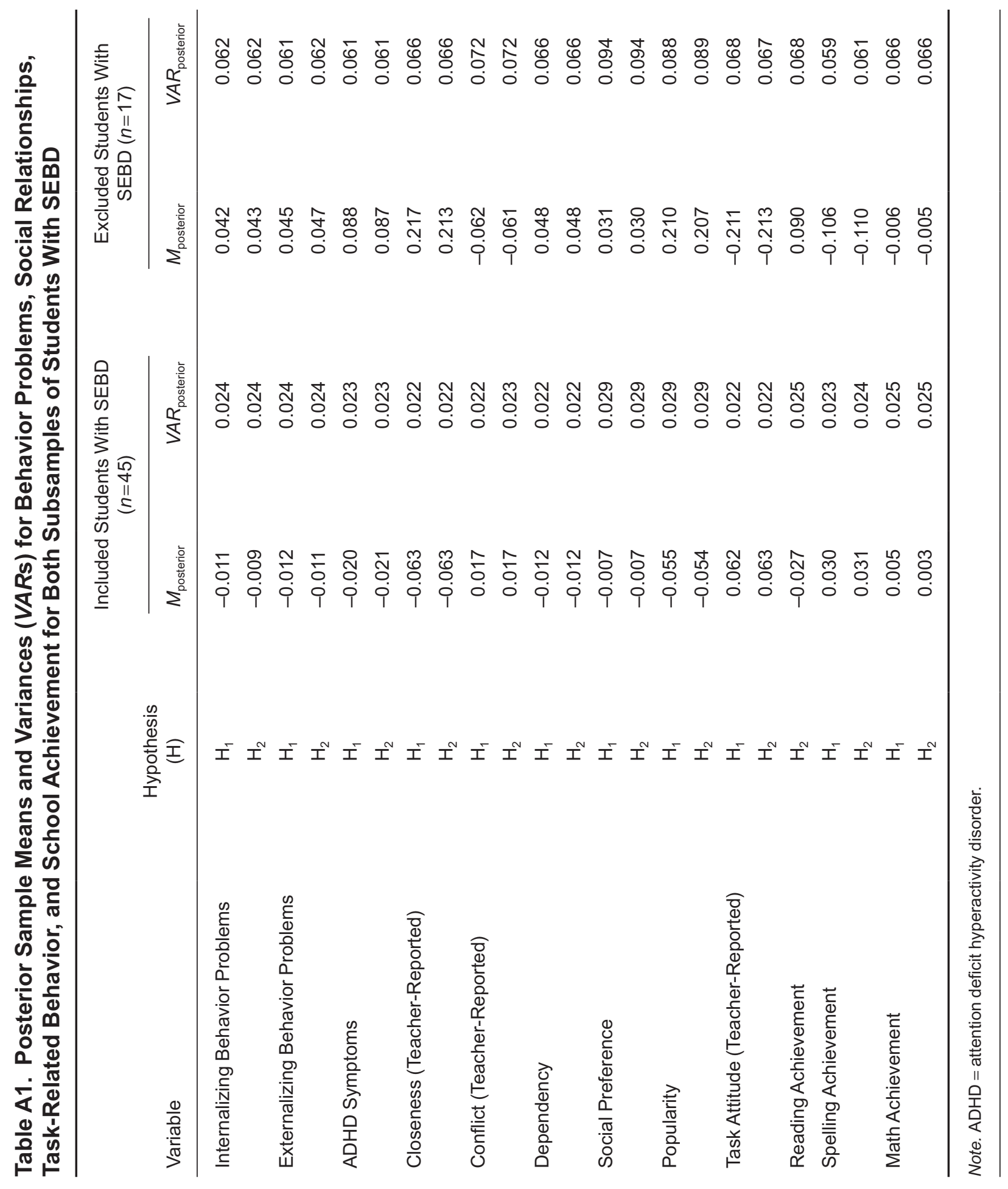




\begin{tabular}{|c|c|c|c|c|c|}
\hline \multirow[b]{2}{*}{ Variable } & \multirow[b]{2}{*}{ Hypothesis (H) } & \multicolumn{2}{|c|}{$\begin{array}{l}\text { Included Students } \\
\text { With SEBD }(n=45)\end{array}$} & \multicolumn{2}{|c|}{$\begin{array}{l}\text { Excluded Students } \\
\text { With SEBD }(n=17)\end{array}$} \\
\hline & & $M_{\text {posterior }}$ & $V A R_{\text {posterior }}$ & $M_{\text {posterior }}$ & $V A R_{\text {posterior }}$ \\
\hline \multirow[t]{3}{*}{ Class } & $\mathrm{H}_{1}$ & -0.108 & 0.021 & 0.354 & 0.062 \\
\hline & $\mathrm{H}_{2}$ & -0.107 & 0.021 & 0.353 & 0.063 \\
\hline & $\mathrm{H}_{3}$ & -0.107 & 0.021 & 0.355 & 0.062 \\
\hline \multirow[t]{3}{*}{ School } & $\mathrm{H}_{1}$ & -0.049 & 0.023 & 0.161 & 0.066 \\
\hline & $\mathrm{H}_{2}$ & -0.049 & 0.023 & 0.163 & 0.065 \\
\hline & $\mathrm{H}_{3}$ & -0.049 & 0.022 & 0.160 & 0.066 \\
\hline \multirow[t]{2}{*}{ Workload } & $\mathrm{H}_{1}$ & 0.080 & 0.023 & -0.249 & 0.064 \\
\hline & $\mathrm{H}_{2}$ & 0.079 & 0.023 & -0.250 & 0.062 \\
\hline \multirow[t]{2}{*}{ Benefits } & $\mathrm{H}_{1}$ & 0.110 & 0.023 & -0.345 & 0.064 \\
\hline & $\mathrm{H}_{2}$ & 0.111 & 0.023 & -0.346 & 0.064 \\
\hline \multirow[t]{2}{*}{ Challenges } & $\mathrm{H}_{1}$ & 0.015 & 0.024 & -0.045 & 0.066 \\
\hline & $\mathrm{H}_{2}$ & 0.015 & 0.024 & -0.048 & 0.066 \\
\hline \multirow[t]{2}{*}{ Excluded } & $\mathrm{H}_{1}$ & 0.117 & 0.022 & -0.392 & 0.058 \\
\hline & $\mathrm{H}_{2}$ & 0.118 & 0.021 & -0.390 & 0.059 \\
\hline
\end{tabular}

Note. Class=teacher self-efficacy in the classroom context; School=teacher self-efficacy in the school context; Workload=teacher workload and management; Benefits=inclusion benefits and level of disability; Challenges=learning challenges in inclusive education; Excluded=excluded students.

on each scale were summed to calculate a total score per narrow-band or broadband scale. $T$ scores and percentile scores for students' sum scores were calculated by a scoring program based on norm data of students of the same sex and age. Percentile scores of $0-92$ were classified as normal, percentile scores of 93-96 were classified as subclinical, and percentile scores of 97-100 were classified as clinical.

The Dutch Sociaal-Emotionele Vragenlijst (SocialEmotional Questionnaire [SEV]; Scholte \& Van der Ploeg, 2007) is a behavioral questionnaire to measure problems in the social-emotional development of children aged 4-18 years. The SEV contains four dimensions: Attention-Deficit With Hyperactivity, Social Behavior Problems, Anxiety and Mood-Disordered Behavior, and Autistic Behavior. For four of these dimensions, specific subdimensions are distinguished. Attention-Deficit With Hyperactivity consists of three subdimensions: Attention-Deficit (six items; e.g., "The child loses materials that are required for tasks at school or at home"), Hyperactivity (six items, e.g.; "The child is easily distracted"), and Impulsivity (six items; e.g., "The child finds it difficult to wait for his/her turn, for instance during playing games"). Social Behavior Problems consists of Oppositional-Defiant Behavior (eight items; e.g.,
"The child intentionally annoys other people"), Aggressive Behavior (six items; e.g., "The child starts fights or gets easily involved in fights"), and Antisocial Behavior (12 items; e.g., "The child steals at home or somewhere else outside of home"). Anxiety and Mood-Disordered Behavior consists of General Anxious Behavior (six items; e.g., "The child is worried easily or frets about things a lot"), Social Anxiety Behavior (six items; e.g., "The child does not step up for himself/herself"), and Anxious-Depressed Behavior (six items; e.g., "The child is unhappy, sad, gloomy"). Autistic Behavior does not contain any subdimensions (10 items; e.g., "The child cannot take another person's perspective"). Teachers had to rate on a 5-point scale (ranging from $0=$ the behavior does not occur to $4=$ the behavior occurs very often or daily) how often the student with SEBD showed the described behavioral aspects in the past half year. Students' scores on each scale were summed to calculate a total score per dimension or subdimension. Percentile scores for students' sum scores were looked up in a table of normative data of students of the same sex and age. Percentile scores of 0-89 were classified as normal, percentile scores of 90-94 were classified as subclinical, and percentile scores of 95-100 were classified as clinical. 


\section{Table A3. Posterior Sample Means and Variances (VARs) for Self-Perceived Social-Emotional Functioning of Typically Developing Students and Included and Excluded Students With SEBD}

\begin{tabular}{|c|c|c|c|c|c|c|c|}
\hline \multirow[b]{2}{*}{ Variable } & \multirow{2}{*}{$\begin{array}{l}\text { Hypothesis } \\
(\mathrm{H})\end{array}$} & \multicolumn{2}{|c|}{$\begin{array}{l}\text { Typically Developing } \\
\text { Students }(n=772)\end{array}$} & \multicolumn{2}{|c|}{$\begin{array}{l}\text { Included Students } \\
\text { With SEBD }(n=45)\end{array}$} & \multicolumn{2}{|c|}{$\begin{array}{l}\text { Excluded Students } \\
\text { With SEBD }(n=17)\end{array}$} \\
\hline & & $M_{\text {posterior }}$ & $V A R_{\text {posterior }}$ & $M_{\text {posterior }}$ & $V A R_{\text {posterior }}$ & $M_{\text {posterior }}$ & $V A R_{\text {posterior }}$ \\
\hline \multirow[t]{3}{*}{ Closeness (Student-Reported) } & $\mathrm{H}_{1}$ & 0.037 & 0.001 & -0.518 & 0.023 & -0.309 & 0.070 \\
\hline & $\mathrm{H}_{2}$ & 0.037 & 0.001 & -0.518 & 0.022 & -0.311 & 0.070 \\
\hline & $\mathrm{H}_{3}$ & 0.037 & 0.001 & -0.517 & 0.022 & -0.311 & 0.070 \\
\hline \multirow[t]{3}{*}{ Conflict (Student-Reported) } & $\mathrm{H}_{1}$ & -0.051 & 0.001 & 0.618 & 0.022 & 0.810 & 0.076 \\
\hline & $\mathrm{H}_{2}$ & -0.051 & 0.001 & 0.618 & 0.022 & 0.811 & 0.076 \\
\hline & $\mathrm{H}_{3}$ & -0.051 & 0.001 & 0.619 & 0.022 & 0.813 & 0.077 \\
\hline \multirow[t]{3}{*}{ Negative Expectations } & $\mathrm{H}_{1}$ & -0.026 & 0.001 & 0.352 & 0.022 & 0.280 & 0.069 \\
\hline & $\mathrm{H}_{2}$ & -0.026 & 0.001 & 0.352 & 0.023 & 0.280 & 0.069 \\
\hline & $\mathrm{H}_{3}$ & -0.026 & 0.001 & 0.352 & 0.023 & 0.278 & 0.070 \\
\hline \multirow[t]{3}{*}{ Relationship With Peers } & $\mathrm{H}_{1}$ & 0.044 & 0.001 & -0.643 & 0.022 & -0.406 & 0.069 \\
\hline & $\mathrm{H}_{2}$ & 0.045 & 0.001 & -0.642 & 0.023 & -0.405 & 0.068 \\
\hline & $\mathrm{H}_{3}$ & 0.044 & 0.001 & -0.643 & 0.023 & -0.406 & 0.068 \\
\hline \multirow{3}{*}{$\begin{array}{l}\text { Task Attitude } \\
\text { (Student-Reported) }\end{array}$} & $\mathrm{H}_{1}$ & 0.061 & 0.001 & -0.819 & 0.022 & -0.787 & 0.068 \\
\hline & $\mathrm{H}_{2}$ & 0.061 & 0.001 & -0.821 & 0.022 & -0.788 & 0.067 \\
\hline & $\mathrm{H}_{3}$ & 0.061 & 0.001 & -0.818 & 0.022 & -0.787 & 0.067 \\
\hline \multirow[t]{3}{*}{ Self-Esteem } & $\mathrm{H}_{1}$ & 2.957 & 0.001 & 2.705 & 0.009 & 2.984 & 0.028 \\
\hline & $\mathrm{H}_{2}$ & 2.956 & 0.001 & 2.704 & 0.009 & 2.986 & 0.028 \\
\hline & $\mathrm{H}_{3}$ & 2.956 & 0.001 & 2.705 & 0.009 & 2.986 & 0.029 \\
\hline \multirow[t]{3}{*}{ Attitude Toward School } & $\mathrm{H}_{1}$ & 3.354 & 0.000 & 3.037 & 0.008 & 3.010 & 0.023 \\
\hline & $\mathrm{H}_{2}$ & 3.354 & 0.000 & 3.037 & 0.008 & 3.010 & 0.023 \\
\hline & $\mathrm{H}_{3}$ & 3.354 & 0.000 & 3.037 & 0.008 & 3.008 & 0.023 \\
\hline
\end{tabular}

\section{REFERENCES}

American Psychiatric Association. (2000). Diagnostic and statistical manual of mental disorders (4th ed., text revision). Arlington, VA: Author.

Avramidis, E., \& Norwich, B. (2002). Teachers' attitudes toward integration/ inclusion: A review of the literature. European Journal of Special Needs Education, 17(2), 129-147. doi:10.1080/08856250210129056

Bailey, J. (2004). The validation of a scale to measure school principals' attitudes toward the inclusion of students with disabilities in regular schools. Australian Psychologist, 39(1), 76-87. doi:10.1080/000500604100016 60371

Bailey, J., \& Du Plessis, D. (1998). An investigation of school principals' attitudes toward inclusion. Australasian Journal of Special Education, 22(1), 12-29. doi:10.1080/1030011980220104

Becker, S. P., Paternite, C. E., Evans, S. W., Andrews, C., Christensen, O. A., Kraan, E. M., \& Weist, M. D. (2011). Eligibility, assessment, and educational placement issues for students classified with emotional disturbance: Federal and state-level analyses. School Mental Health, 3(1), 24-34. doi:10.1007/s12310-010-9045-2

Bijstra, J. (2004). Een onderzoek naar het gebruik van toelatingscriteria tot het cluster 4 onderwijs [An investigation of the use of eligibility criteria for cluster 4 education]. Tijdschrift voor Orthopedagogiek,
43, 488-497. Retrieved from http://www.100jaarorthopedagogiek. $\mathrm{nl} / \mathrm{q}=2004$

Boivin, M., Petitclerc, A., Feng, B., \& Barker, E. D. (2010). The developmental trajectories of peer victimization in middle to late childhood and the changing nature of their behavioral correlates. Merrill-Palmer Quarterly, 56(3), 231-260. doi:10.1353/mpq.0.0050

Breeman, L. D., Wubbels, T., van Lier, P. A. C., Verhulst, F. C., van der Ende, J., Maras, A., ... Tick, N. T. (2015). Teacher characteristics, social classroom relationships, and children's social, emotional, and behavioral classroom adjustment in special education. Journal of School Psychology, 53, 87-103. doi:10.1016/j.jsp.2014.11.005

Bruggink, M. (2015). Teachers' perceptions of students' additional support needs (Doctoral Dissertation). Vrije Universiteit Amsterdam, Amsterdam, The Netherlands.

Brus, B. T., \& Voeten, M. J. M. (2006). Een-Minuut-Test. Verantwoording en Handleiding [One-minute reading fluency test: Psychometric validation and manual]. Amsterdam, The Netherlands: Harcourt Assessment BV.

Buttner, S., Pijl, S. J., Bijstra, J., \& Van den Bosch, E. (2016). Personality traits of expert teachers of students with EBD: Clarifying a teacher's $\mathrm{X}$-factor. International Journal of Inclusive Education, 20(6), 569-587. doi:10.1080/13603116.2015.1100222 
Cannon, Y., Gregory, M., \& Waterstone, J. (2013). A solution hiding in plain sight: Special education and better outcomes for students with social, emotional and behavioral challenges. Fordham Urban Law Journal, 41, 403-497. Retrieved from https://dash.harvard.edu/handle/1/12073910

Chansky, T. E., \& Kendall, P. C. (1997). Social expectancies and self-perceptions in anxiety-disordered children. Journal of Anxiety Disorders, 11(4), 347-363. doi:10.1016/S0887-6185(97)00015-7

Cillessen, A. H. N. (2009). Sociometric methods. In K. H. Rubin, W. M. Bukowski, \& B. Laursen, (Eds.), Handbook of peer interactions, relationships and groups (pp. 82-99). New York, NY: Guilford Press.

Cito. (2011). VISEON: Volginstrument voor sociaal-emotionele ontwikkeling Handleiding digitale toetsen [VISEON: Monitoring instrument for social-emotional development. Digital test manual]. Arnhem, The Netherlands: Author.

Citogroep. (2004). VISEON: Volginstrument voor Sociaal-Emotionele Ontwikkeling Verantwoording [VISEON: Monitoring instrument for social-emotional development Psychometric validation]. Arnhem, The Netherlands: Author.

Crnic, K., \& Neece, C. (2015). Socioemotional consequences of illness and disability. In M. E. Lamb \& R. M. Lerner (Eds.), Handbook of child psychology and developmental science: Vol. 3. Socioemotional processes (pp. 287-323). Hoboken, NJ: Wiley. doi:10.1002/9781118963418

David, C. F., \& Kistner, J. A. (2000). Do positive self-perceptions have a "dark side"? Examination of the link between perceptual bias and aggression. Journal of Abnormal Child Psychology, 28(4), 327-337. doi:10.1023/A:1005164925300

De Greef, E. E. M., \& Van Rijswijk, C. M. (2006). De groei van de deelname aan cluster 4: opvattingen over oorzaken en groeibeperkende maatregelen [The increased participation in cluster 4: Opinions about causes and measures to limit growth]. Den Haag, The Netherlands: Landelijke Commissie Toezicht Indicatiestelling.

De Roos, M., \& Bloem, M. (2014). Uit het voortgezet speciaal onderwijs, en wat dan? (Report of the Centraal Bureau voor de StatistiekSociaaleconomische trends, oktober 2014, 02) [Out of secondary special education, what next? (Report of the Central Agency of Statistics Socio-economic trends]. Retrieved from https://www.cbs.nl/NR/ rdonlyres/525202E8-151D-4C73-8BC2-A5E0B12A802D/0/2014Uithetvoorgezetspeciaalonderwijsendanart.pdf

De Vos, T. (2011). Tempotest Automatiseren Handleiding en Verantwoording [Arithmetic processing speed test manual and psychometric validation]. Amsterdam, The Netherlands: Boom test uitgevers.

Den Brok, P., Brekelmans, M., \& Wubbels, T. (2004). Interpersonal teacher behaviour and student outcomes. School Effectiveness and School Improvement: An International Journal of Research, Policy and Practice, 15(3-4), 407-442. doi:10.1080/09243450512331383262

Drost, M., \& Bijstra, J. O. (2008). Leerlingen in beeld: Een onderzoek naar kenmerken van leerlingen die worden aangemeld voor het cluster 4-onderwijs [Students in the spotlight: An investigation of characteristics of students who apply for Cluster 4 education]. Groningen, The Netherlands: Regionaal Expertise Centrum Noord Nederland, Cluster 4 (RENN4).

Egyed, C. J., \& Short, R. J. (2006). Teacher self-efficacy, burnout, experience and decision to refer a disruptive student. School Psychology International, 27, 462-474. doi:10.1177/0143034306070432

Ekornås, B., Heimann, M., Tjus, T., Heyerdahl, S., \& Lundervold, A. J. (2011). Primary school children's peer relationships: Discrepancies in self-perceived social acceptance in children with emotional or behavioral disorders. Journal of Social and Clinical Psychology, 30(6), 570-582. doi:10.1521/jscp.2011.30.6.570

Evers, A., Lucassen, W., Meijer, R., \& Sijtsma, K. (2010). COTAN beoordelingssysteem voor de kwaliteit van tests [COTAN evaluation system for the quality of tests]. Zaandijk, The Netherlands: Heijnis \& Schipper.

Farmer, T. W., \& Hollowell, J. H. (1994). Social networks in mainstream classrooms: Social affiliations and behavioral characteristics of students with EBD. Journal of Emotional and Behavioral Disorders, 2, 143-155.

Flower, A., McKenna, J. W., Haring, C. D., \& Pazey, B. (2015). Schoolto-life transition: Perceptions of youth in behavior intervention programs. Preventing School Failure, 59(4), 217-226. doi:10.1080/104 5988X.2014.917602

Friedman, I. A., \& Kass, E. (2002). Teacher self-efficacy: A classroom-organization conceptualization. Teaching and Teacher Education, 18(6), 675-686. doi:10.1016/S0742-051X(02)00027-6

Furlong, M. J., Morrison, G. M., \& Jimerson, S. R. (2004). Externalizing behaviors of aggression and violence and the school context. In R. B. Rutherford Jr, M. M. Quinn, \& S. R. Mathur, (Eds.), Handbook of research in emotional and behavioral disorders (pp. 243-261). New York, NY: Guilford Press.

Geelhoed, J., \& Reitsma, P. (2004). PI-dictee [PI spelling dictation task]. Amsterdam, The Netherlands: Pearson Assessment and Information B.V.

Gibbs, S., \& Powell, B. (2012). Teacher efficacy and pupil behaviour: The structure of teachers' individual and collective beliefs and their relationship with numbers of pupils excluded from school. Journal of Educational Psychology, 82, 564-584. doi:10.1111/j.2044-8279.2011.02046.x

Goei, S. L., \& Kleijnen, R. (2009). Eindrapportage: Literatuurstudie onderwijsraad "omgang met zorgleerlingen met gedragsproblemen" [Final report: Review educational council "handling students with special educational needs due to behavior problems"]. Zwolle, The Netherlands: Christelijke Hogeschool Windesheim.

Gresham, F. M., \& Kern, L. (2004). Internalizing behavior problems in children and adolescents. In R. B. Rutherford Jr., M. M. Quinn, \& S. R. Mathur, (Eds.), Handbook of research in emotional and behavioral disorders (pp. 262-281). New York, NY: Guilford Press.

Hendriksen, J. G. M., \& Hurks, P. P. M. (2009). Technische handleiding WPPSI-III-NL [Technical manual WPPSI-III-NL]. Amsterdam, The Netherlands: Pearson Assessment and Information B.V.

Hoijtink, H. J. A. (2012). Informative hypotheses: Theory and practice for behavioral and social scientists. Boca Raton, FL: Chapman \& Hall/CRC.

Hoijtink, H., Klugkist, I., \& Boelen, P. A. (2008). Bayesian evaluation of informative hypotheses. New York, NY: Springer.

Hughes, J. N., Barker, D., Kemenoff, S., \& Hart, M. (1993). Problem ownership, causal attributions, and self-efficacy as predictors of teachers' referral decisions. Journal of Educational \& Psychological Consultation, 4 , 369-384.

Inspectorate of Education. (2013). Professionalisering als gerichte opgave: Verkennend onderzoek naar het leren van leraren [Professional development as a directional challenge: Exploratory research on learning of teachers]. Utrecht, The Netherlands: Author. Retrieved from https://www. onderwijsdatabank.nl/84148/professionalisering-als-gerichte-opgave/

Jellesma, F. C., Zee, M., \& Koomen, H. M. Y. (2015). Children's perceptions of the relationship with the teacher: Associations with appraisals and internalizing problems in middle childhood. Journal of Applied Developmental Psychology, 36, 30-38. doi:10.1016/j.appdev.2014.09.002

Jones, H. A., \& Chronis-Tuscano, A. (2008). Efficacy of teacher in-service training for attention-deficit/hyperactivity disorder. Psychology in the Schools, 45, 918-929. doi:10.1002/pits.20342

Kass, R. E., \& Raftery, A. E. (1995). Bayes factors. Journal of the American Statistical Association, 90(430), 773-795. doi:10.2307/2291091

Kauffman, J. M., \& Badar, J. (2014). It's instruction over place - not the other way around! Phi Delta Kappan, 98(4), 55-59. doi:10.1177/0031721716681778

Klugkist, I., Laudy, O., \& Hoijtink, H. (2005). Inequality constrained analysis of variance: A Bayesian approach. Psychological Methods, 10(4), 477-493. doi:10.1037/1082-989X.10.4.477

Konijn, E. A., Van de Schoot, R., Winter, S. D., \& Ferguson, C. J. (2015). Possible solution to publication bias through Bayesian statistics, including proper null hypothesis testing. Communication Methods and Measures, 9 , 280-302. doi:10.1080/19312458.2015.1096332

Koomen, H. M. Y., \& Jellesma, F. C. (2015). Can closeness, conflict, and dependency be used to characterize students' perceptions of the affective relationship with their teacher? Testing a new child measure in middle childhood. British Journal of Education, 85(4), 479-497. doi:10.1111/ bjep. 12094

Koomen, H. M. Y., Verschueren, K., \& Pianta, R. C. (2007). LLRV leerling Leerkracht Relatie Vragenlijst Handleiding [LLRV student teacher 
relationship questionnaire manual]. Houten, The Netherlands: Bohn Stafleu van Loghum.

Koomen, H. M. Y., Verschueren, K., Van Schooten, E., Jak, S., \& Pianta, R. C. (2012). Validating the student-teacher relationship scale: Testing factor structure and measurement invariance across child gender and age in a Dutch sample. Journal of School Psychology, 50, 215-234. doi:10.1016/j. jsp.2011.09.001

Kort, W., Schittekatte, M., Dekker, P. H., Verhaeghe, P., Compaan, E. L., Bosmans, M., \& Vermeir, G. (2005). WISC-IIINL: Wechsler intelligence scale for children - third edition (David wechsler): Handleiding en verantwoording. Amsterdam, The Netherlands: Pearson Assessment and Information B.V.

Landrum, T. (2011). Emotional and behavioral disorders. In J. M. Kauffman \& D. P. Hallahan (Eds.), Handbook of special education (pp. 209-220). New York, NY: Routledge.

Lane, K. L., Wehby, J. H., Little, M. A., \& Cooley, C. (2005). Academic, social, and behavioral profiles of students with emotional and behavioral disorders educated in self-contained classrooms and self-contained schools: Part I - Are they more alike than different? Behavioral Disorders, $30,349-361$.

LCTI. (2006). De groei van deelname aan cluster 4: opvattingen over oorzaken en groeibeperkende maatregelen [Growth of special education participation: Attitudes about causes and growth restriction policies]. Den Haag, The Netherlands: Landelijke Commissie Toezicht Indicatiestelling. Retrieved from https://docplayer.nl/14760362-De-groei-van-de-deelname-aan-cluster-4-opvattingen-over-oorzaken-en-groeibeperkendemaatregelen.html

Ledoux, G., Roeleveld, J., Van Langen, A., \& Smeets, E. (2012). Cool speciaal. inhoudelijk rapport (Rapport 884, projectnummer 20476) [Cool speciaal: Theoretical report]. Amsterdam, The Netherlands: Kohnstamm Instituut.

Legerstee, J. S., Van der Reijden-Lakeman, I. A., Lechner-Van der Noort, M. G., \& Ferdinand, R. F. (2004). Bruikbaarheid verkorte versie WISC-RN in de kinderpsychiatrie [Feasibility of the shortened WISC-RN in child psychiatry]. Kind en Adolescent, 25(4), 178-182. doi:10.1007/BF03060926

Little, M., \& Kobak, R. (2003). Emotional security with teachers and children's stress reactivity: A comparison of special-education and regular-education classrooms. Journal of Clinical Child and Adolescent Psychology, $32,127-138$.

Lynn, S., Carroll, A., Houghton, S., \& Cobham, V. (2013). Peer relations and emotion regulation of children with emotional and behavioural difficulties with and without a developmental disorder. Emotional and Behavioural Difficulties, 18(3), 297-309. doi:10.1080/13632752.2013.769707

Maassen, G. H., Van Boxtel, H. W., \& Goossens, F. A. (2005). Reliability of nominations and two-dimensional ratings scale methods for sociometric status determination. Journal of Applied Developmental Psychology, 26(1), 51-68. doi:10.1016/j.appdev.2004.10.005

Maassen, G. H., \& Verschueren, K. (2005). A two-dimensional ratings-based procedure for sociometric status determination as an alternative to the Asher and Dodge system. Merrill-Palmer Quarterly, 51(2), 192-212. doi:10.1353/mpq.2005.0011

Marks, P. E. L., Babcock, B., Cillessen, A. H. N., \& Crick, N. R. (2013). The effects of participation rate on the internal reliability of peer nomination measures. Social Development, 22(3), 609-622. doi:10.1111/j.1467-9507.2012.00661.x

McKenna, J. W., Kim, M. K., Shin, M., \& Pfannenstiel, K. (2017). An evaluation of single-case reading intervention study quality for students with and at risk for emotional and behavioral disorders. Behavior Modification, 41(6), 868-906. doi:10.1170/0145445517701896

Meijer, C. J. W. (2001). Inclusive education and effective classroom practices. Brussels, Belgium: European Agency for Development in Special Needs Education. Retrieved from https://www.european-agency.org/publications/ereports/inclusive-education-and-effective-classroom-practice/ inclusive-education-and-effective-classroom-practice

Meijer, C. J. W. (2003). Special education across Europe in 2003: Trends in provision in 18 European countries. Brussels, Belgium: European Agency for Development in Special Needs Education. Retrieved from https:// www.european-agency.org/

Meijer, C. J. W., \& Foster, S. F. (1988). The effect of teacher self-efficacy on referral chance. Journal of Special Education, 22, 378-385.

Mulder, J., Hoijtink, H., \& De Leeuw, C. (2012). BIEMS: A Fortran 90 program for calculating Bayes factors for inequality and equality constrained models. Journal of Statistical Software, 46(2), 1-39. doi:10.18637/jss.v046.i02

Mulder, J., Hoijtink, H., \& Klugkist, I. (2010). Equality and inequality constrained multivariate linear models: Objective model selection using constrained posterior priors. Journal of Statistical Planning and Inference, 140(4), 887-906. doi:10.1016/j.jspi.2009.09.022

Mulder, J., Klugkist, I., Van de Schoot, R., Meeus, W. H. J., Selfhout, M., \& Hoijtink, H. (2009). Bayesian model selection of informative hypotheses for repeated measurements. Journal of Mathematical Psychology, 53(6), 530-546. doi:10.1016/j.jmp.2009.09.003

Oh-Young, C., \& Filler, J. (2015). A meta-analysis of the effects of placement on academic and social skill outcome measures of students with disabilities. Research in Developmental Disabilities, 47, 80-92. doi:10.1016/j. ridd.2015.08.014

Orobio de Castro, B., Brendgen, M., Van Boxtel, H., Vitaro, F., \& Schaepers, L. (2007). "Accept me, or else...": Disputed overestimation of social competence predicts increases in proactive aggression. Journal of Abnormal Child Psychology, 35(2), 165-178. doi:10.1007/s10802-006-9063-6

Poulin, F., \& Boivin, M. (2000). The role of proactive and reactive aggression in the formation and development of boys' friendships. Developmental Psychology, 36, 233-240. doi:10.1037/0012-1649.36.2.233

Reid, R., Gonzalez, J. E., Nordness, P. D., Trout, A., \& Epstein, M. H. (2004) A meta-analysis of the academic status of students with emotional/behavioral disturbance. The Journal of Special Education, 38, 130-143. doi:10. $1177 / 00224669040380030101$

Ruijs, N. M., \& Peetsma, T. T. D. (2009). Effects of inclusion on students with and without special educational needs reviewed. Educational Research Review, 4, 67-79. doi:10.1016/j.edurev.2009.02.002

Scholte, E. M., \& Van der Ploeg, J. D. (2007). Sociaal-Emotionele Vragenlijst (SEV) Handleiding [Social-Emotional Questionnaire manual]. Houten, The Netherlands: Bohn Stafleu van Loghum.

Solis, M., Vaughn, S., Swanson, E., \& McCulley, L. (2012). Collaborative models of instruction: The empirical foundations of inclusion and co-teaching. Psychology in the Schools, 49, 498-510. doi:10.1002/ pits. 21606

Soodak, L. C., \& Podell, D. M. (1993). Teacher efficacy and student problem as factors in special education referral. The Journal of Special Education, $27,66-81$.

Stoutjesdijk, R., \& Scholte, E. M. (2009). Cluster 4 speciaal onderwijs: een vergelijking tussen leerlingen op cluster 4 scholen en cluster 4 rugzakleerlingen [Cluster 4 special education: A comparison between students in special education and students included in regular education]. Tijdschrift voor Orthopedagogiek, 48, 161-169. Retrieved from https://docplayer. nl/13968572-Cluster-4-speciaal-onderwijs-een-vergelijking-tussen-leerlingen-op-cluster-4-scholen-en-cluster-4-rugzakleerlingen.html

Stoutjesdijk, R., Scholte, E. M., \& Swaab, H. (2012). Special needs characteristics of children with emotional and behavioral disorders that affect inclusion in regular education. Journal of Emotional and Behavioral Disorders, 20(2), 92-104. doi:10.1177/1063426611421156

Tankersley, M., Landrum, T. J., \& Cook, B. G. (2004). How research informs practice in the field of emotional and behavioral disorders. In R. B. Rutherford, Jr., M. M. Quinn, \& S. R. Mathur, (Eds.), Handbook of research in emotional and behavioral disorders (pp. 98-113). New York, NY: Guilford Press.

Tejeda-Delgado, M. D. C. (2009). Teacher efficacy, tolerance, gender, and years of experience and special education referrals. International Journal of Special Education, 24(1), 112-119.

Tick, N. T., Van der Ende, J., \& Verhulst, F. C. (2007). Twenty-year trends in emotional and behavioral problems in Dutch children in a changing society. Acta Psychiatrica Scandinavica, 116(6), 473-482. doi:10.1111/j.1600-0447.2007.01068.x 
Tsouloupas, C. N., Carson, R. L., Matthews, R. A., Grawitch, M. J., \& Barber, L. K. (2010). Exploring the association between teachers' perceived student misbehaviour and emotional exhaustion: The importance of teacher efficacy beliefs and emotion regulation. Educational Psychology: An International Journal of Experimental Educational Psychology, 30(2), 173-189. doi:10.1080/01443410903494460

United Nations. (2006). Convention on the rights of persons with disabilities (CRPD). Retrieved from https://www.un.org/development/desa/disabilities/convention-on-the-rights-of-persons-with-disabilities.html

Useche, A. C., Sullivan, A. L., Merk, W., \& Orobio de Castro, B. (2014). Relationships of aggression subtypes and peer status among aggressive boys in general education and emotional/behavioral disorder (EBD) classrooms. Exceptionality, 22(2), 111-128. doi:10.1080/09362835.2013.865529

Van de Schoot, R., Hoijtink, H., Mulder, J., Van Aken, M. A., Orobio de Castro, B., Meeus, W., \& Romeijn, J.-W. (2011). Evaluating expectations about negative emotional states of aggressive boys using Bayesian model selection. Developmental Psychology, 47, 203-212. doi:10.1037/a0020957

Van de Schoot, R., Mulder, J., Hoijtink, H., Van Aken, M. A. G., Dubas, J. S., Orobio de Castro, B., ... Romeijn, J.-W. (2011). An introduction to Bayesian model selection for evaluating informative hypotheses. European Journal of Developmental Psychology, 8(6), 713-729. doi:10. 1080/17405629.2011.621799

Van der Veen, I., Smeets, E., \& Derriks, M. (2010). Pupils with special educational needs in the Netherlands: Number, characteristics, and school career. Educational Research, 52(1), 15-43. doi:10.1080/00131881003588147

Van Leeuwen, B., Thijs, A., \& Zandbergen, M. (2009). Inclusive education in the Netherlands (Report No. AN 2.4624.165). Enschede, The Netherlands: AXIS Media-ontwerpers.
Verhulst, F. C., \& Van der Ende, J. (2013). Handleiding ASEBA Vragenlijsten voor leeftijden 6 tot en met 18 jaar [Manual ASEBA Questionnaires for ages 6 to 18]. Rotterdam, The Netherlands: ASEBA Nederland.

Wagner, M., Kutash, K., Duchnowski, A. J., Epstein, M. H., \& Sumi, W. C. (2005). The children and youth we serve: A national picture of the characteristics of students with emotional disturbances receiving special education. Journal of Emotional and Behavioral Disorders, 13(2), 79-96.

Walraven, M., Kieft, M., \& Broekman, L. (2011). Passend onderwijs aan leerlingen met gedragsproblemen [Suitable education for students with behavior problems]. Utrecht, The Netherlands: Oberon. Retrieved from https://www.oberon.eu/ons-portfolio/item/passend-onderwijs-aanleerlingen-met-gedragsproblemen.html

Zakriski, A. L., \& Prinstein, M. J. (2001). Sociometric status of child inpatients in clinical and normative peer groups: Is peer status in a clinical setting a useful measure of adjustment? Applied Developmental Psychology, 22(2), 157-173. doi:10.1016/S0193-3973(01)00074-0

Zee, M., \& De Bree, E. (2017). Students' self-regulation and achievement in basic reading and math skills: The role of student-teacher relationships in middle childhood. European Journal of Developmental Psychology, 14(3), 265-280. doi:10.1080/17405629.2016.1196587

Zee, M., \& Koomen, H. M. Y. (2016). Teacher self-efficacy and its effects on classroom processes, student academic adjustment and teacher wellbeing: A synthesis of 40 years of research. Review of Educational Research, 86(4), 981-1015. doi:10.3102/0034654315626801

Date Received: February 1, 2017

Date Accepted: June 28, 2018

Associate Editor: Tanya Eckert

\section{AUTHOR BIOGRAPHICAL STATEMENTS}

Inge Zweers, PhD, currently is a postdoctoral researcher at the Free University of Amsterdam (VU Amsterdam), the Netherlands. At VU Amsterdam, she examines the effects of inquiry-based learning for students with special educational needs. In addition, Inge works as a research coordinator at an institution for upper secondary vocational education and training (ROC van Twente). Her research at ROC van Twente focuses on teacher professionalization and improving learning processes, student involvement, and student well-being at school.

Jan O. Bijstra, PhD, is a research coordinator at the Regional Centre of Expertise for EBD Schools (RENN4) in Groningen, the Netherlands. His research focuses on how to support teachers of students with EBD and how to improve the educational curriculum and learning outcomes of students with EBD. In addition, he is collaborating with different universities in supervising doctoral students in the field of developmental psychology.

Bram Orobio de Castro, $\mathrm{PhD}$, is a full professor of developmental psychopathology at Utrecht University, The Netherlands. His research group studies prevention and intervention for behavior problems among children and youth, focusing on experimental innovations, such as a virtual reality cognitive-behavioral therapy. He chairs national programs to reduce bullying and improve effectiveness of intervention for youth in the Netherlands.

Nouchka T. Tick, PhD, works as an assistant professor of developmental psychology at Utrecht University, The Netherlands. Her research interests include student-teacher relationships and student and teacher behavior in schools. Her current research examines the effectiveness of teacher-focused coaching programs among teachers working with students with EBD in regular and special education.

Rens A. G. J. van de Schoot, PhD, works as an associate professor at Utrecht University in the Netherlands and as an extraordinary professor North-West University in South Africa. He is specialized in the inclusion of expert opinions into Bayesian statistical models to deal with small samples and to bring practice and theory closer together. His research interests are various, but he is particularly interested in Bayesian statistics, longitudinal data, and small samples. 
Copyright of School Psychology Review is the property of National Association of School Psychologists and its content may not be copied or emailed to multiple sites or posted to a listserv without the copyright holder's express written permission. However, users may print, download, or email articles for individual use. 